\title{
الوقاية هن الجريمة في الشريعة الإسلامية
}

م. د. بمال عزيز خلف

كلية التربية الأساسية / جامعة واسط

المقدمة

الحمد لله رب العالمين، والصلاة والسلام على سبد المرسلين، وعلى آله وصحبة ومن سار على منهاجه

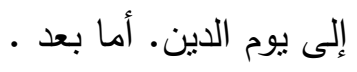

فلا يكاد يوجد دين أو تنريع سماوي أو وضعي يخلو من نظام العقوبات لما له من أهمية كبيرة أو فائدة

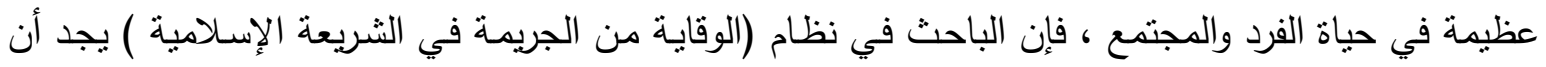

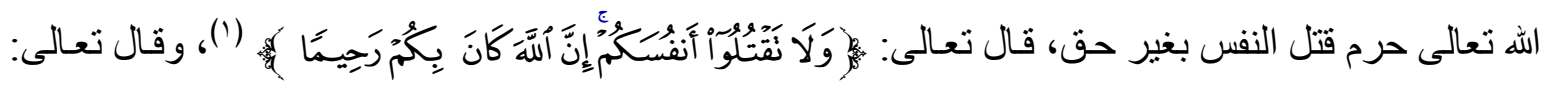

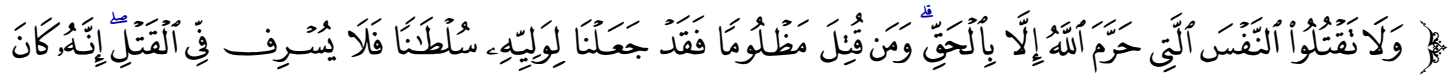

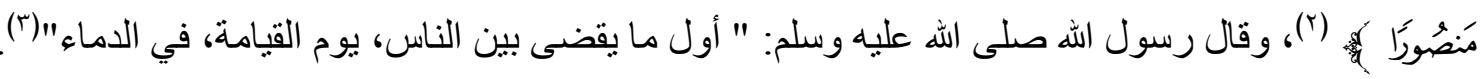
وعظمت عقوبة الاعتداء على النفس المؤمنة في الدنبا والآخرة بما توعد الله به القاتل من غضبه ولعنته

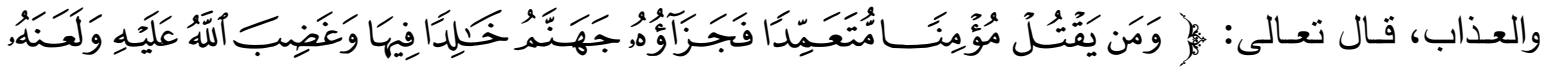

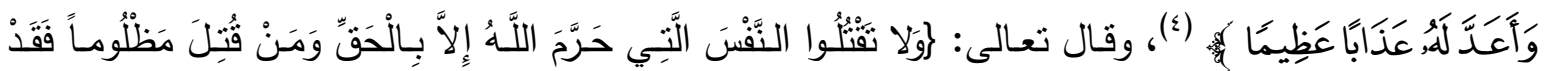

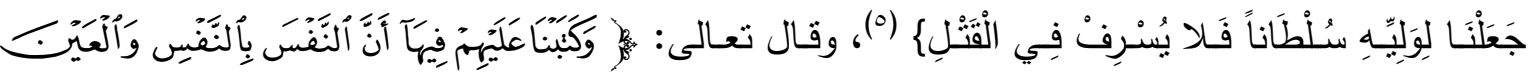

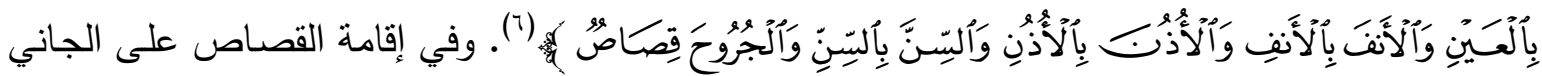

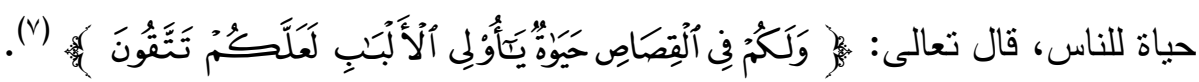
شرع الله تعالى القصاص لمكافحة جريمة القتل، والرذيلة وصيانة المجتمع من الفساد والمعاصي وحماية

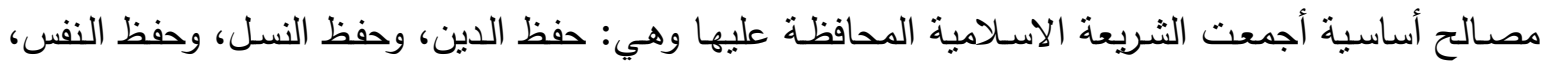

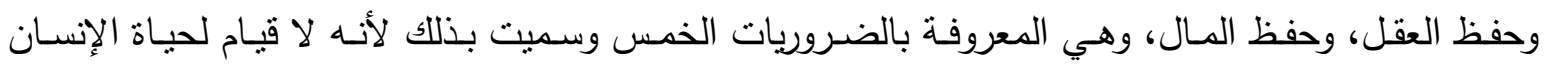
وصلاحه إلا بتوافرها وتواجدها، وحفظها من الاعتداء عليها، وقد أحكم الله سبحانه وتعالى وجوه الزجر الرادعة

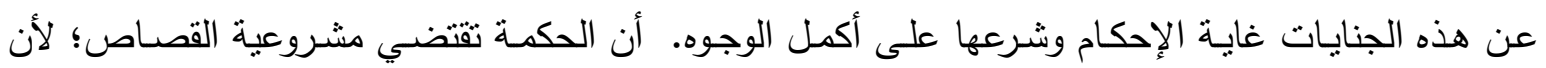

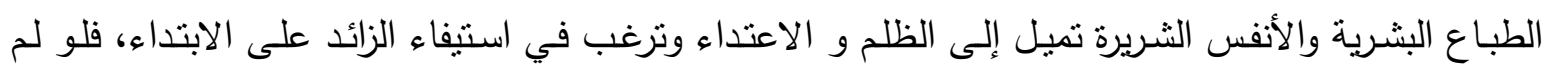

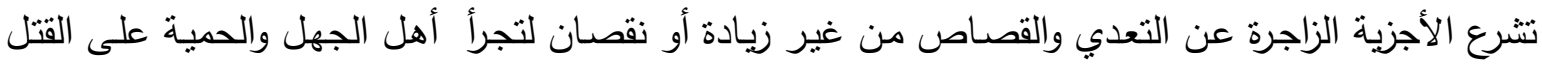

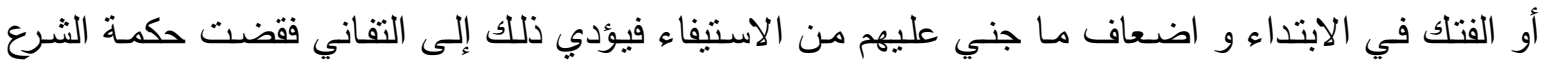

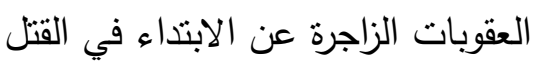
وإن من الأسباب التي دفعتتي إلى دراسـة هذا الموضوع هو ما تعيشـه الأمة من انتشـار القتل، لعدم

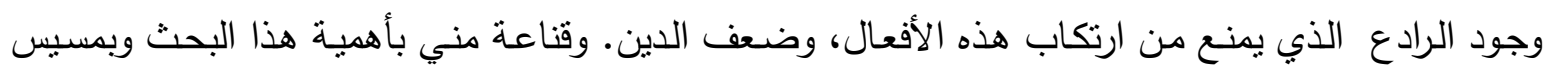

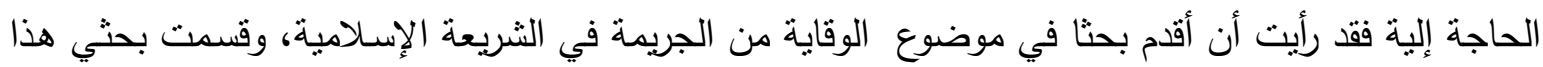
ثلاثة مباحث بعد مقدمة وتمهيد. 
المبحث الأول : الجريمة ومفهومها في الثريعة الإسلامية وفيه ستة مطالب. المبحث الثاني : العوامل الدافعة بالإنسان الى ارتكاب الجريمة وفيه ثلاثة مباحث. المبحث الثالث : السياسة الثرعية لوقاية المجتمع من الجريمة ومعالجتها ـ وفيه ثلاثة مطالب. واسأل اله تعالى أن يجعل هذا العمل المتواضع خالصا لوجهه الكريم، وأن يغفر لي أي خطأ أو زلل وقعت فيه، إنه سميع مجيب.

\section{المبحث الأول- الجريمة وهفهومها في الشريعة الإسلاهية}

المطلب الأول - القتل لغة واصطلاحا

القتل في اللغة : ورد القتل في اللغة بمعان عدة نذكر منها ما يأتي: -

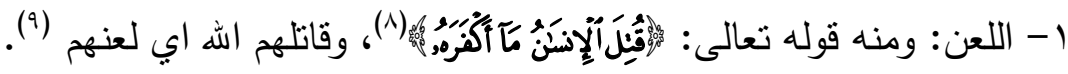

r- المعاداة : كقوله: ( صلى الله عليه وسلم ) قاتل اله اليهود والنصارى (·' اي عاداهم(')" . r-الدفع : كما ورد في حديث السقيفة، (ז') قتل الله سعدا فانه صاحب فنتة وشر، اي دفع الله شره(ז'). ع-المزج : كقولنا قتل الثراب اذا مزجه بالماء(ء) .

0-الخضوع : كقولنا ثقتلت الجارية الرجل حتى عشقها كانها خضعت له (10). צ-وقال فيه صاحب اللسان بانه ( الإماتة بضرب أو حجر أو سم أو علة والمنية قاتلة)(1') القتل في اصطلاحا: أورد فقهاء الثريعة الإسلامية تعريفات عدة للقتل نذكر منها ما يأتي : -

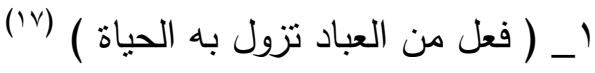

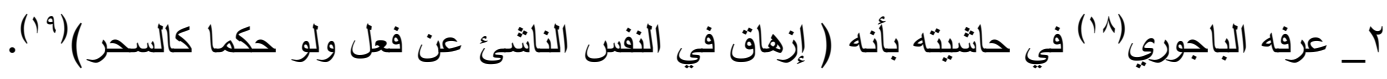

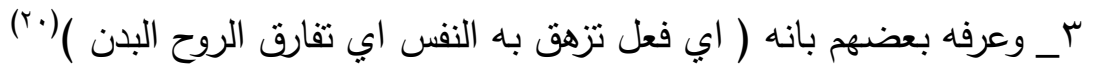
ع- وعرفه الاستاذ عبد القادر عودة (rاr) ( بانـه فعل من العباد نزول بـه الحياة اي ازهاق روح آدمي بفعل آدمي اخر) (r) (r)

ه-وعرفه الاستاذ محمد النبهان بانه ( ازهاق روح انسان بفعل انسان اخر اي فعل من العباد تزول به الحياة )

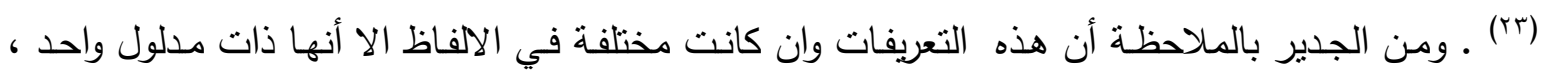

$$
\begin{aligned}
& \text { وهي مفارقة الروح الجسد باي فعل من العباد . } \\
& \text { الهطلب الثانيـ - تهريم قتنل النهسر } \\
& \text { أولا: أدلة تحريمه من الكتاب : }
\end{aligned}
$$

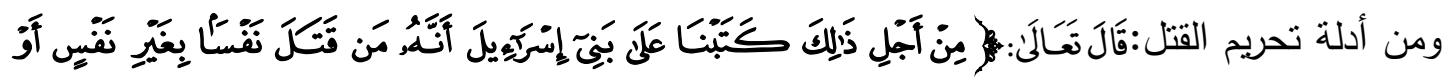

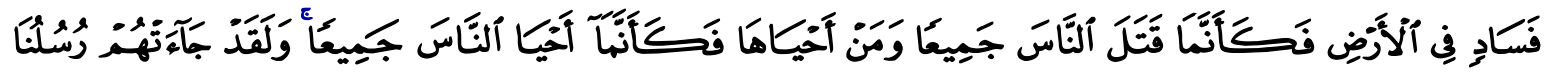




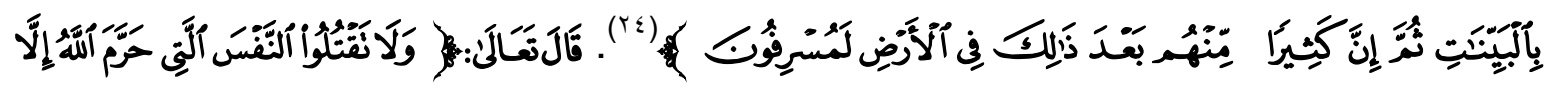

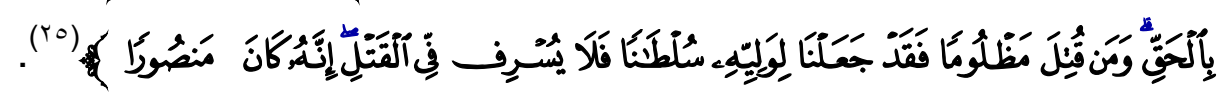

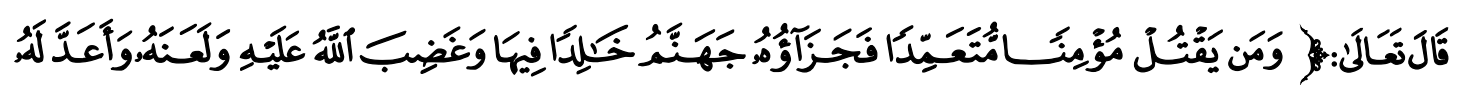

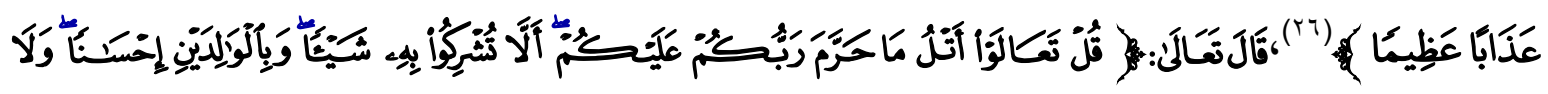

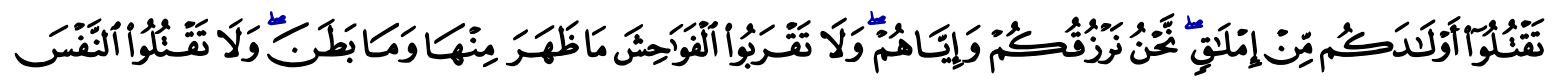

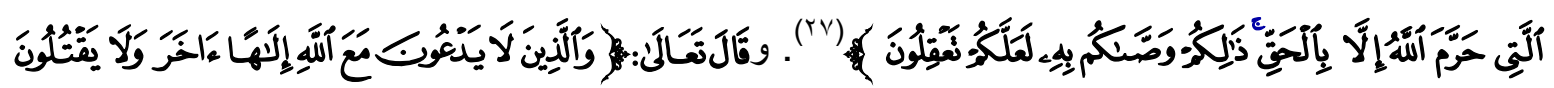

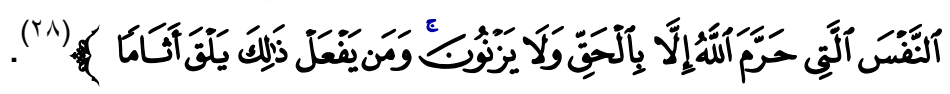
ثانيا :أما أدلة التحريم في السنة فهي:

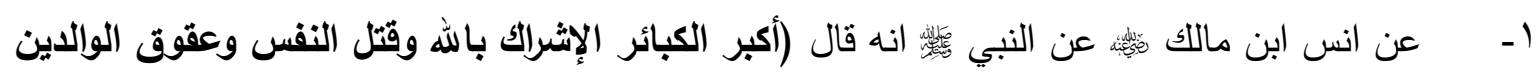

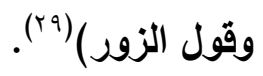

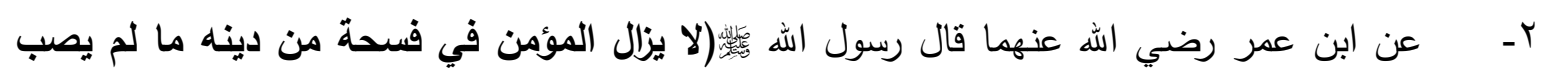

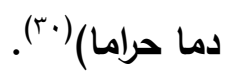

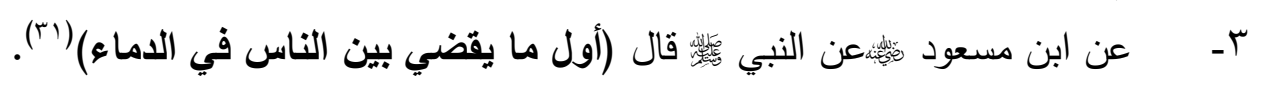

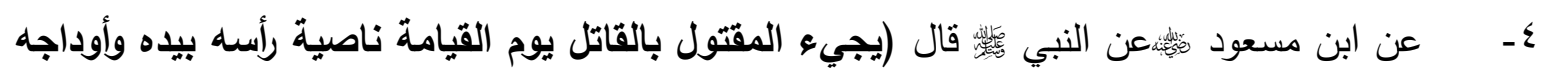

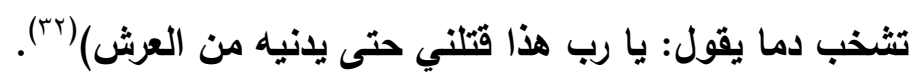

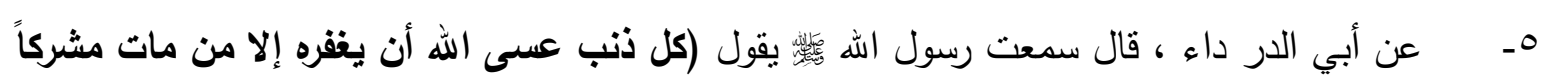

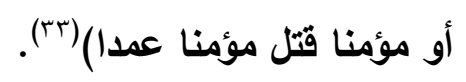

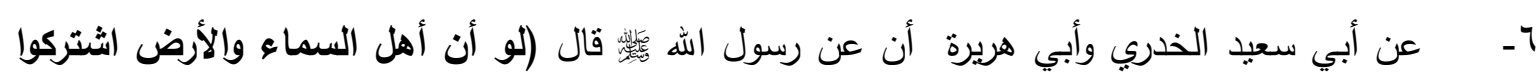

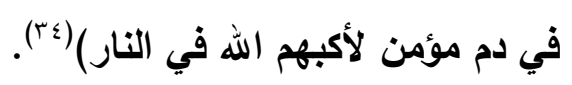

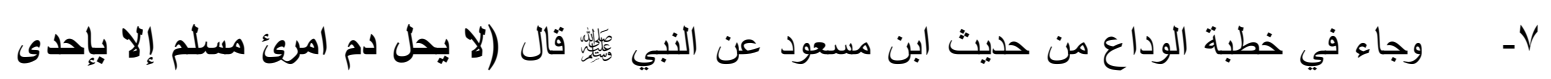

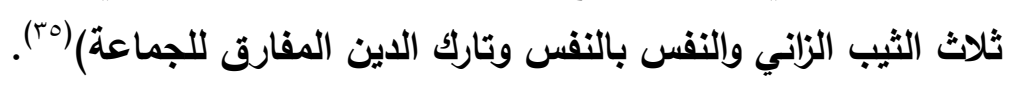

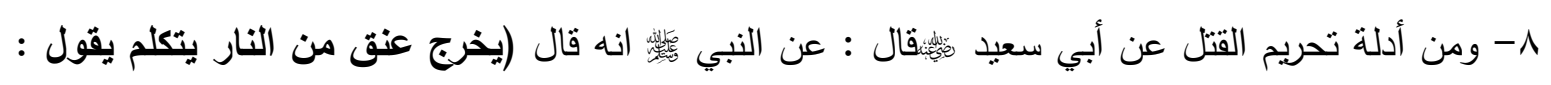

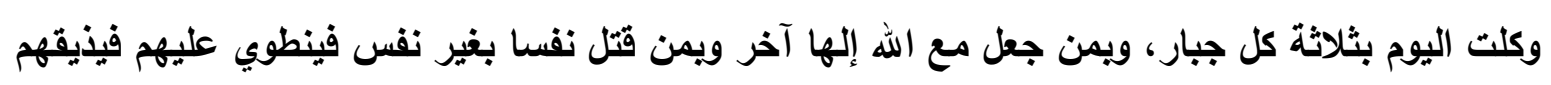

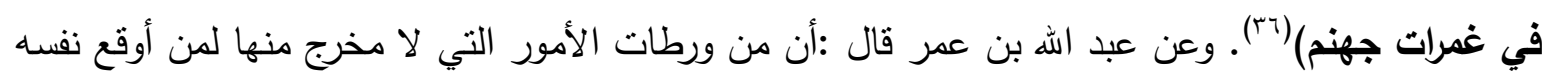

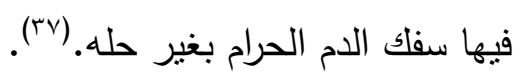

\section{الهطلب الثالث- أنواع القتن والآثار الهترتبة عليه}

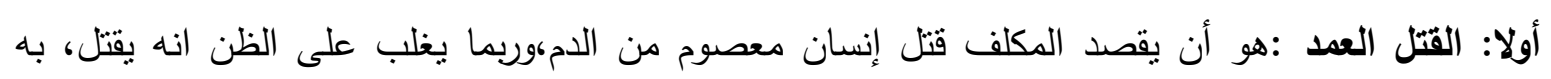

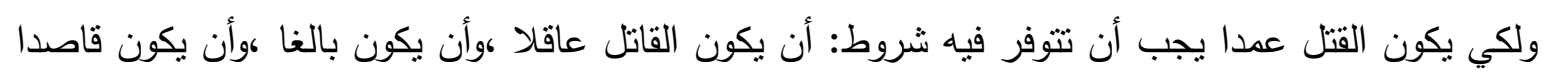

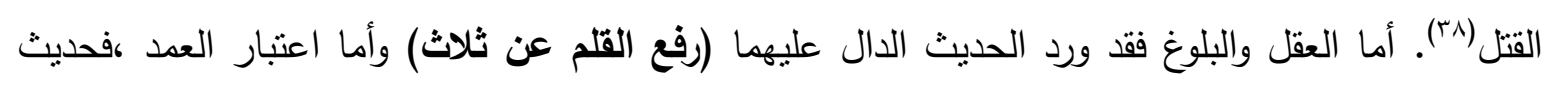

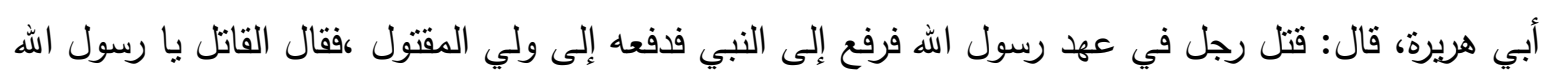




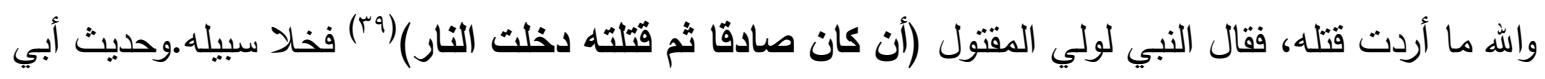

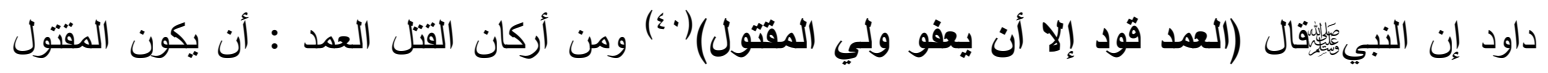

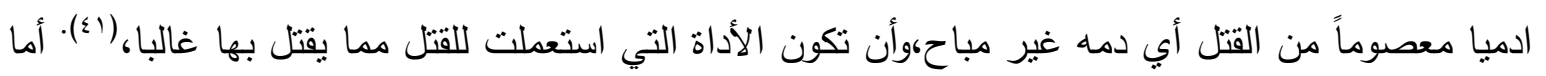

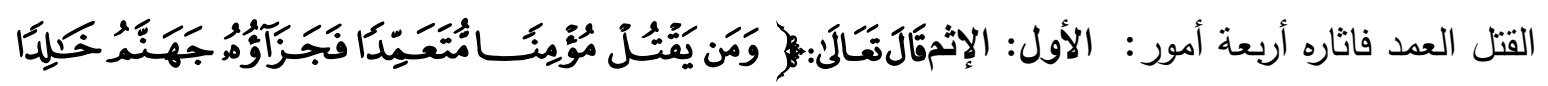

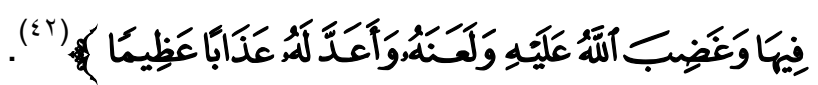

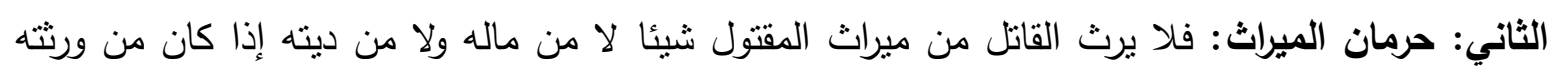

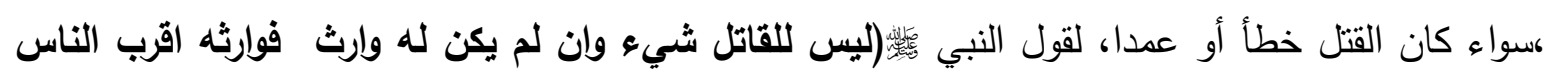

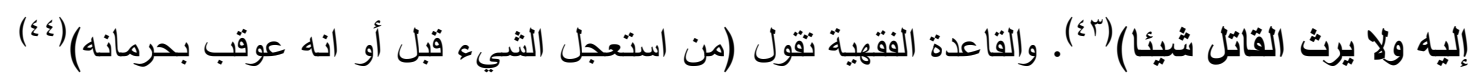

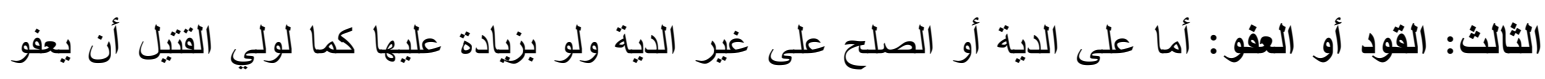

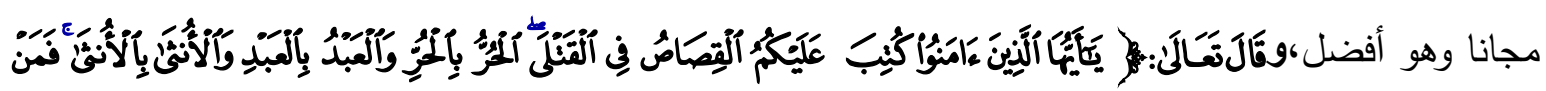

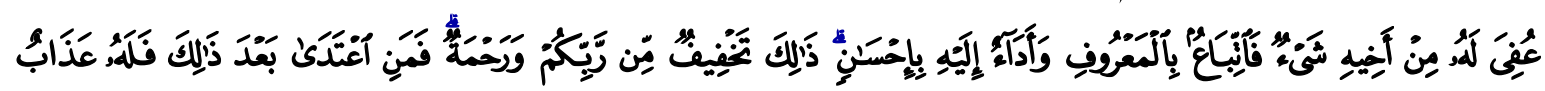

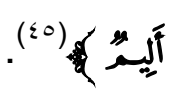

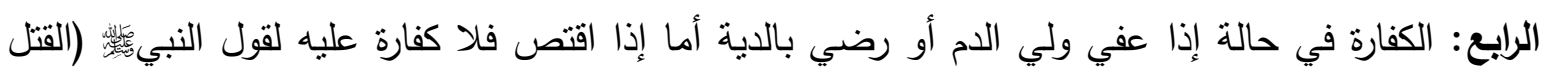

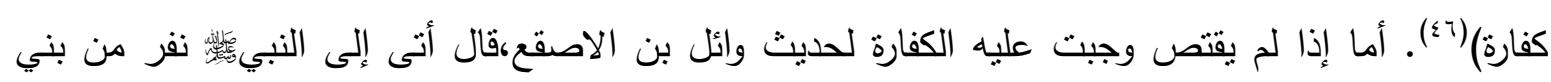

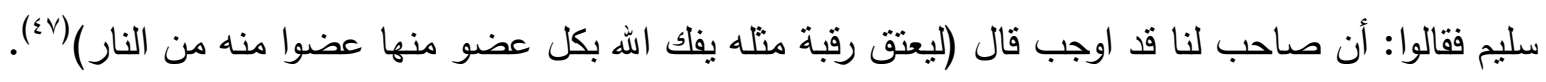

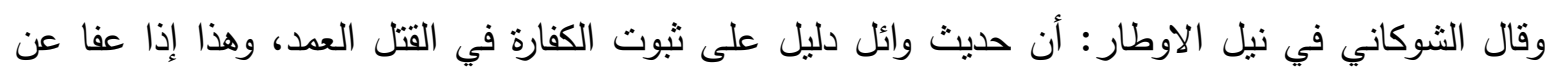

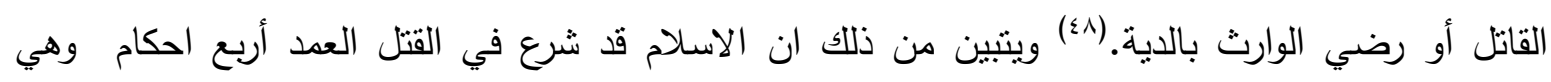

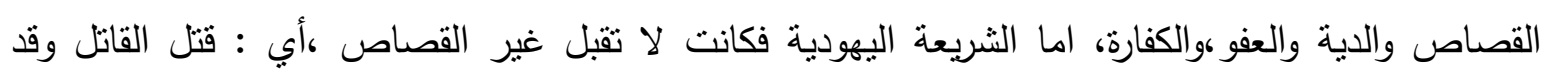

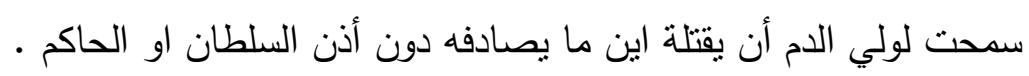

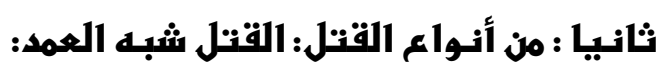

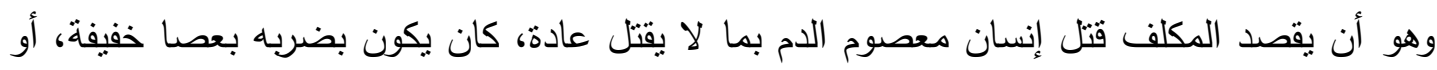

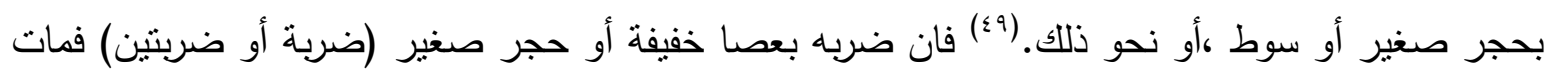

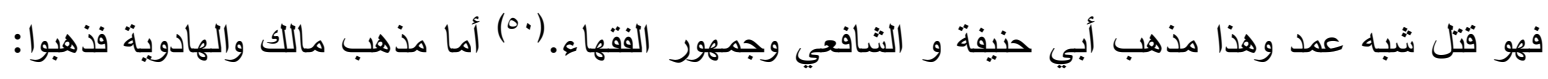

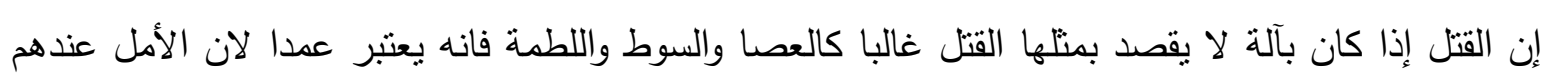

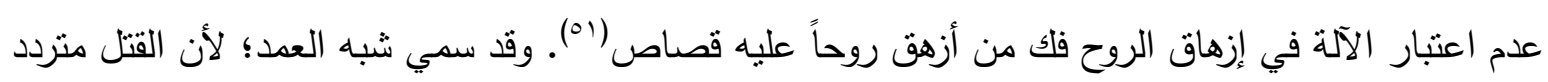

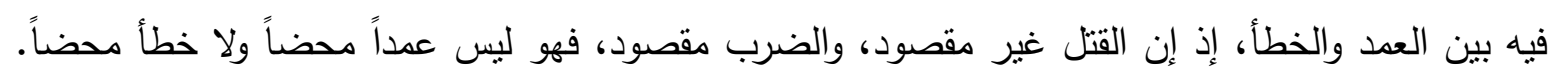

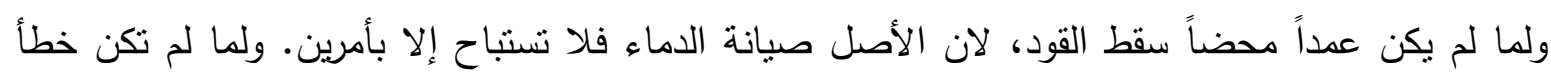

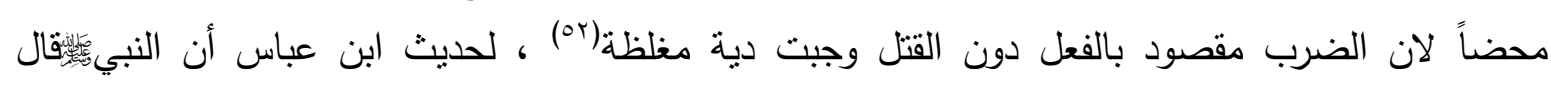

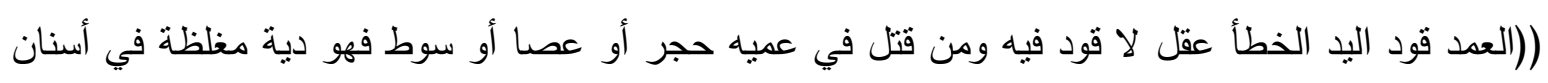

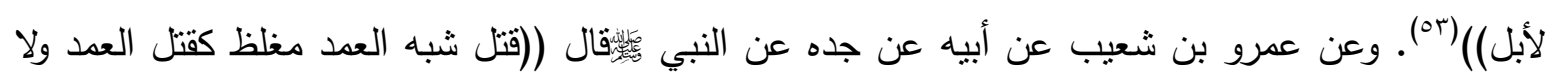

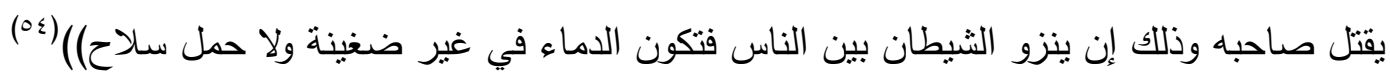


والآثار المترتبة على القتل شبه العمد هي :

الأول : الإثم ؛لأنه قتل نفس حرم الله قتلها.

الثاني: دية مغلظة على العاقل. (00) ثالثا: القتل الخطأ .

هو أن يفعل المكلف ما يباح له فعله كأن برمي جيدا أو يقصد مرضا فيصيب به إنسانا معصوم الدم

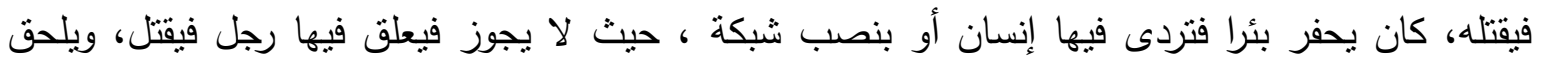

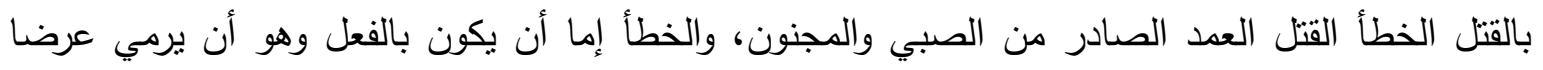

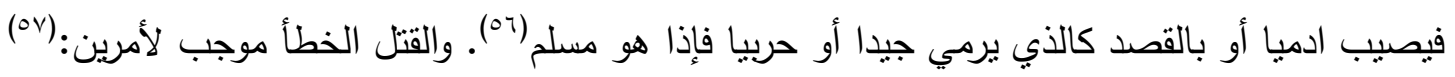
الأول: الدية المخففة على العاقلة مؤجلة ثناث سنين.

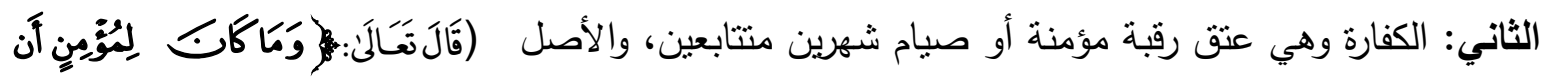

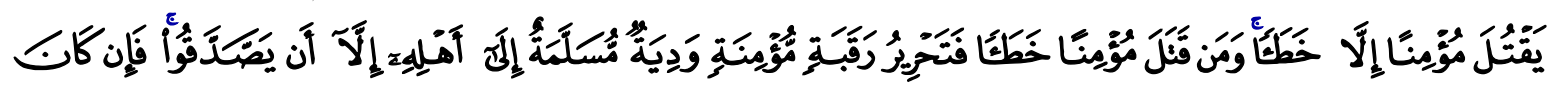

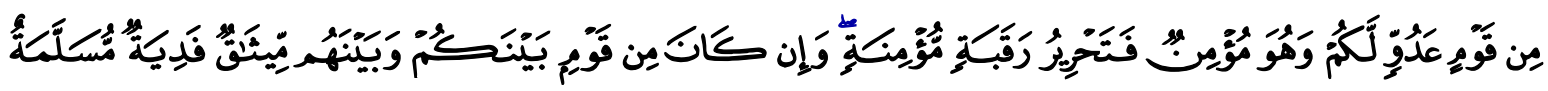

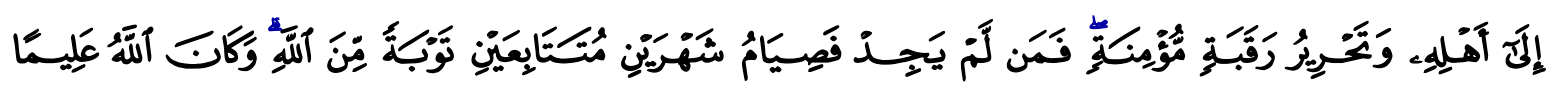

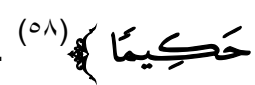
ومن هذا نجد أن حكم القتل الخطأ هو الدية أو الصيام في حكم الثريعة الإسلامية اما عند اليهود فلم

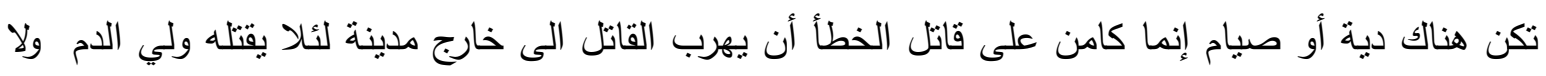
يرجع حتى يموت الكاهن ولكن إن وجده ولي الدم خارج حدود مدينة التي لجئ اليها وقتله ولي الدم فلا دم عليه ولا يجوز ان بدفع فدية لأجل بقائه في مدينتة.

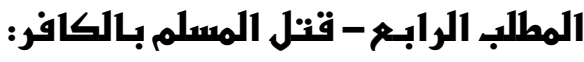

اختلف الفقهاء في هذه القضية إلى ثلاثة مذاهب، وقبل أن نشرع في تفصيل ذلك يجب أن نعرف

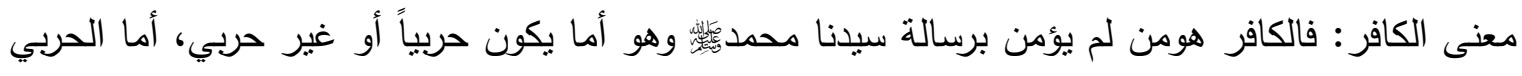

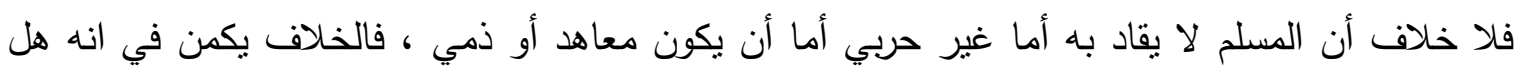
يقاد المسلم بالكافر المعاهد والذمي(هون.

أولا: لا يقاد المسلم بالكافر سواء كان ذمياً أو معاهد ، وهذا مذهب الثافعية والحنابلة والظاهرية وحجتهم في هذا: حديث ساقه البخاري سنده عن مطرف سمعت الثعبي يتحدث قال: سمعت أبا جحيفة قال: سالت عليا

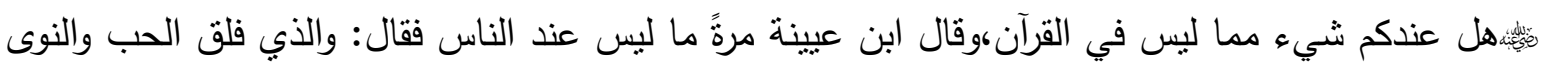

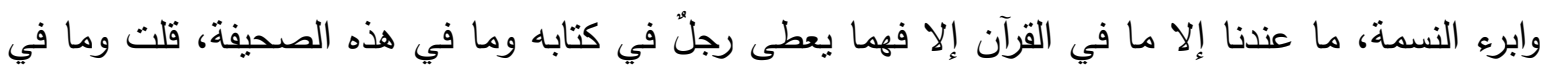

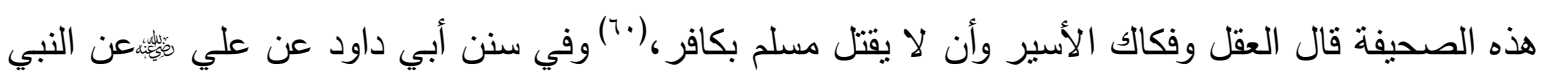
انه قال (المؤمنون تكفأ دماؤهم وهم يد على من سواهم ويسعى بذمتهم أدناهم لا يقتل مؤمن بكافر و لا ذون لون

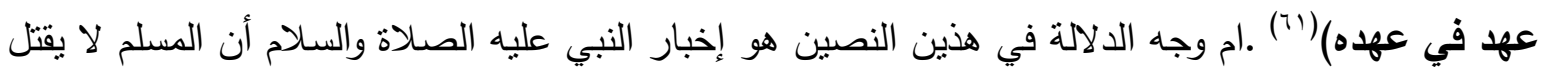

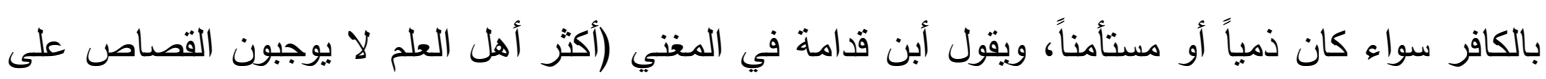


المسلم بقتل الكافر أي كافر كان، وروي ذلك عن عمر وعثمان وعلي وزيد ومعاوية وبه قال عمر بن عبد

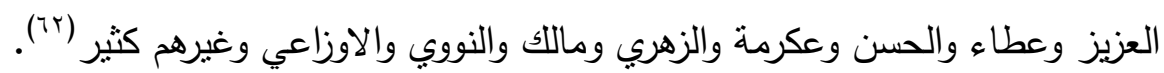

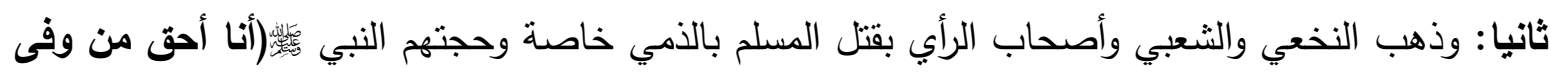
بذمته) (rآ) فلا يقتل؛ لأنه معصوم عصمة مؤبدة

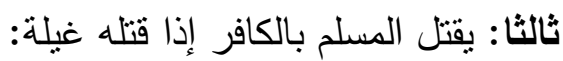

ذهب إلى هذا الرأي الأمام ماللك والليث: قال ماللك لا يقاد المسلم بالكافر إلا أن يقتله غيلة أو حرابة

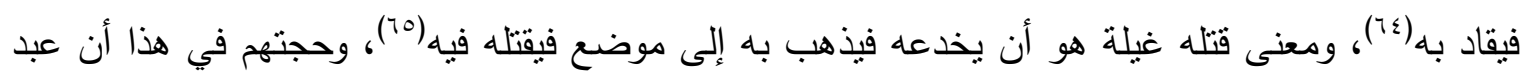

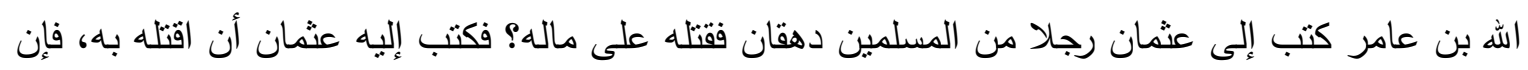
هذا قتل غيلة على الحرابة(ب7).أما اليهود فكما بينا في الفصل الأول من أنهم لا يحرمون قتل الاغيار أي: المسلمين والنصارى ، بل الأمر قد اقتصر على بني جلدتهم ، أب : اليهود فقط هم المعنيون بوصية (لا تقتل ) أما الباقون فأن من واجب اليهودي أن يسفك دمهم.

المطلب الذامسر - قتنل الهر بالعبد

اختلف الفقهاء في مسألة قتل الحر بالعبد منهم من منعه مطلقا ومنهم من أوجبه مطلقا ومنهم من

$$
\text { أوجبه بغير عبده لا بعبد نفسه. }
$$

أما القول الأول: فذكر النووي في المجموع (انه إذا قتل حر عبدا لم يقتل به سواء كان عبده أو عبد غيره

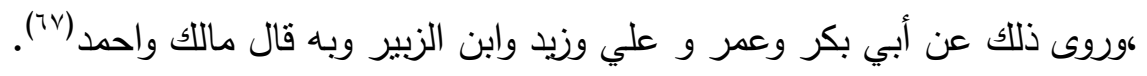

القول الثاني: الحر يقتل بالعبد إذا قتله غيله: قال جمهور المالكية أن الحر يقتل بالعبد مطلقا أن كان القتل على وجه الغيله سواء كان القاتل مسلماً أو كافراً حرا أو عبدا وكذلك المقتول فان كان كل منها يقتل بالآخر. لذا قال ماللك (ولا عفو فيه ولا صلح الولي مردود، والحكم فيه للإمام ،والقتل هنا لبس قصاصا إنما لفساد (^`ت. القول الثالث: يقتل الحر المسلم بالعبد المسلم أن اعتاد قتل العبيد، وبه قال الامامية جاء في شرائع الإسلام

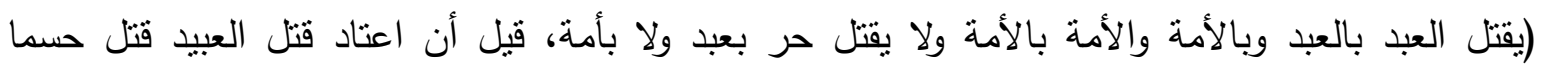

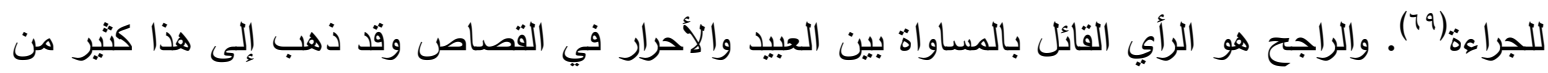
المعاصرين ، يقول فاروق النبهاني : لم يحرم الإسلام الرق في بداية حضوره، ولو فعل لكان ذلك سلاحا فتاكا

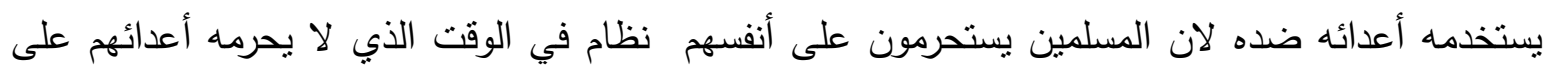

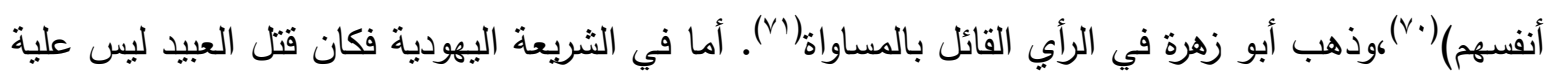
قصاص الا أذا مات في نفس اليوم ، أما اذا بقي يوم أو يومين فلا قصاص لأنه ماله ،كما جاء في سفر بأري (الخروج) (

\section{المطلب السادسر - قتنل الرجل بالمرأة}

القول الأول: يقتل الرجل بالمرأة.ذهب إلى ذلك الأحناف والثافعية والمالكية وجمهور الحنابلة جاء في فتح

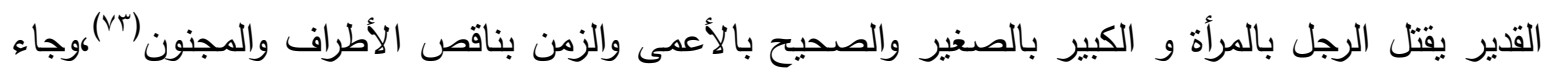


في المغني (أن الذكر يقتل بالأنثى)، وهذا قول عامة أهل العلم منهم ألنخعي والثعبي والزهري و عمر بن عبد

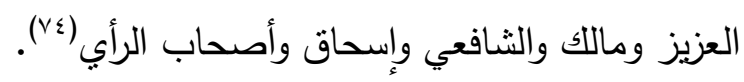

القول الثاني: لا يقتل الرجل بالمرأة ،وهذا هو قول الحسن البصري والليث بن سعد، وقد ذكره الصنعاني في

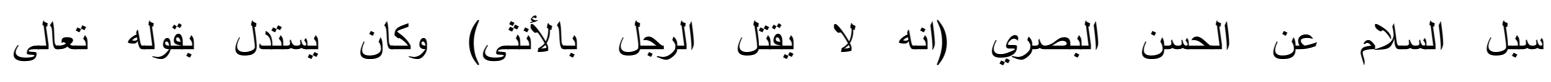

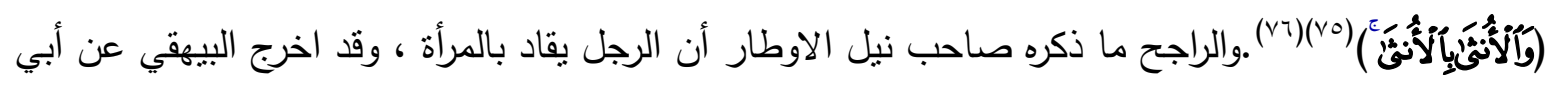
الزناد قال : كان ممن ادر كتهم من فقهائنالذين ينتهي إلى قوله منهم سعيد بن المسيب وعروة بن الزبير

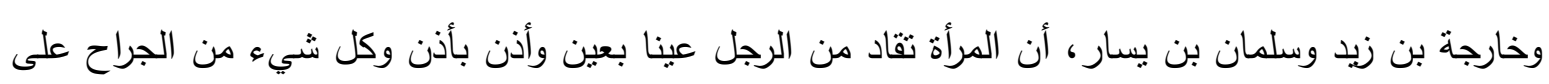

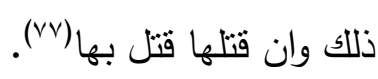

\section{البحث الثاني- العواهل الدافعة بالإنسان الى ارتكاب الجريمة}

\section{المبحث الاول : عوامل تكوبنية وتربوية.}

ان تكوين الثخص وبناءه ونشاته وتربيته قد تكون عاملا لارتكاب الجريمة ، وذلك عندما تكون

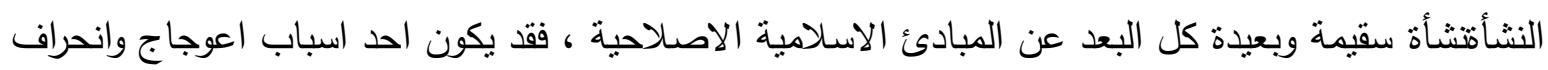

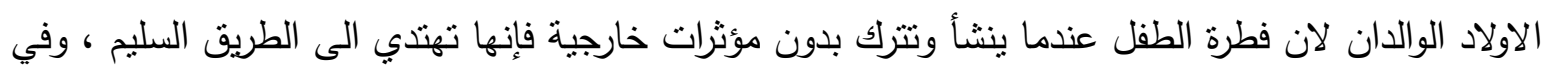

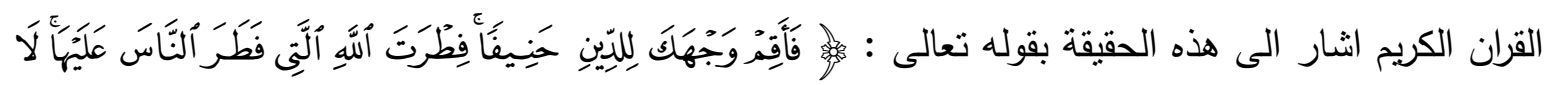

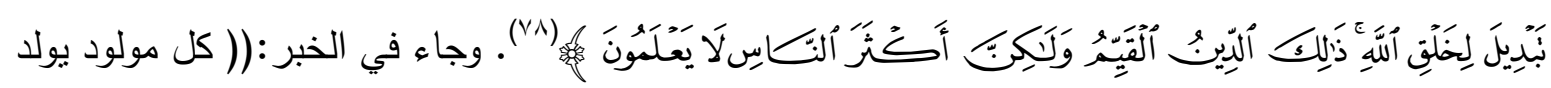

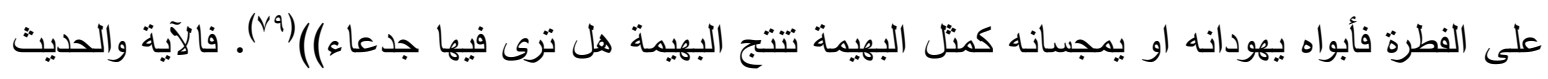

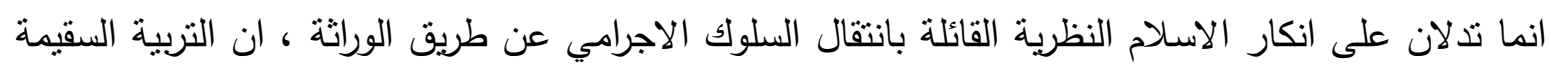

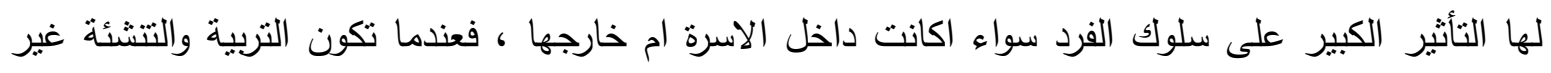

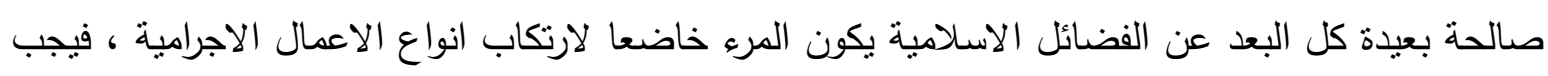

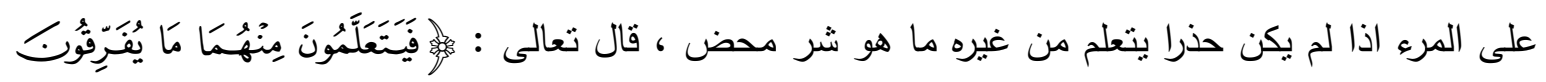

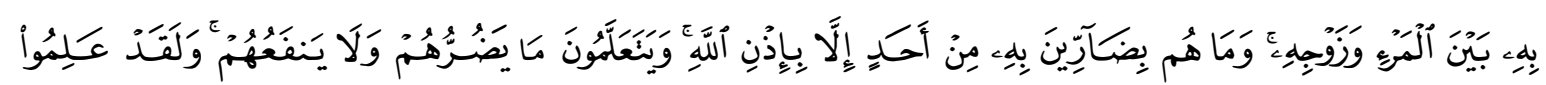

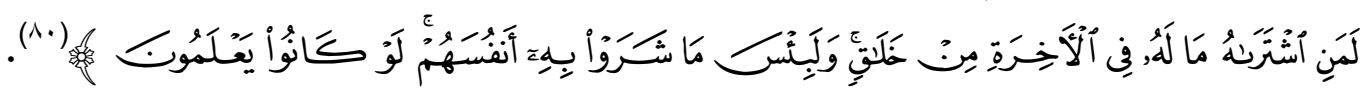

المطلب الثاني : العوامل النفسسية والعقلية .

ان الله تعالى فضل الانسان على سائر مخلوقاته بالعقل ، والعقل من مصادر ادراك الحسن والقبيح ،

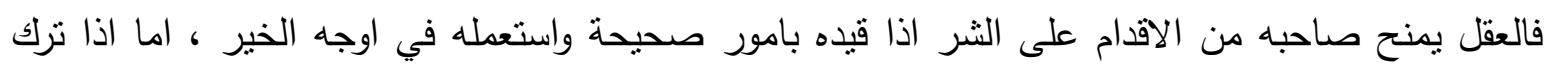

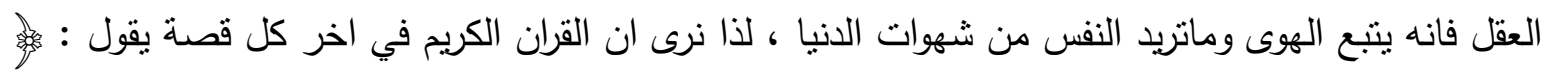

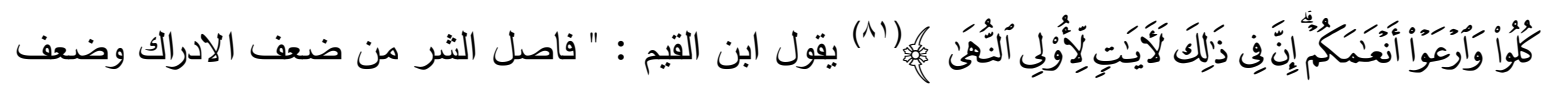

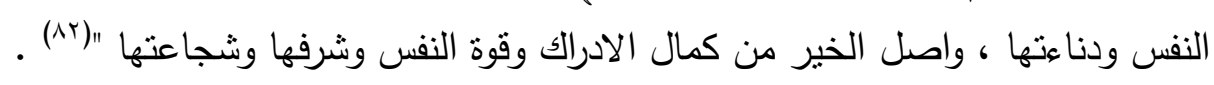

ان النقص في العقل فلا يؤمن الاسلام بحتمية ان يكون نقص العقل عاملا لارتكاب الجريمة ، اذ ان الواقع يثبت ان هناك من ضعاف العقول من لا يرتكبون الجرائم ، وعدم العاقل في نظر الاسلام ليس مكلفا ، 
وبالتالي لا يعاقب على مخالفته ـ. ان النفس البشرية في نظر الاسلام تحتوي في ان واحد على الطاقة التي

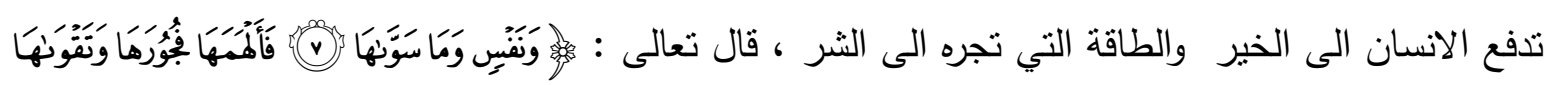

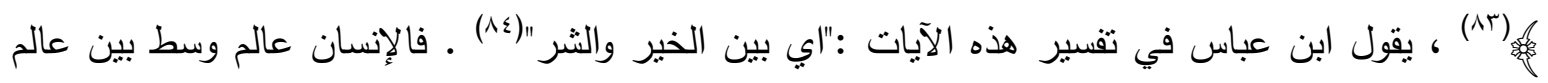

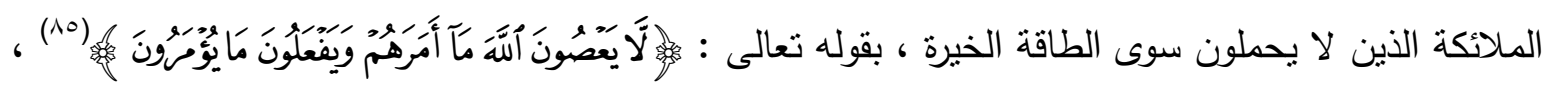

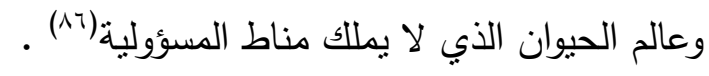

الهطلب الثالث : العوامل البيئية والاجتما عية .

هذه العوامل متعددة ، فمنها ما هي اقتصادية ، واجتماعية ، ومنها ما هي اعلامية وسياسية ، وليس

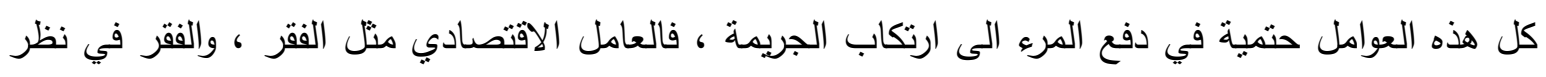

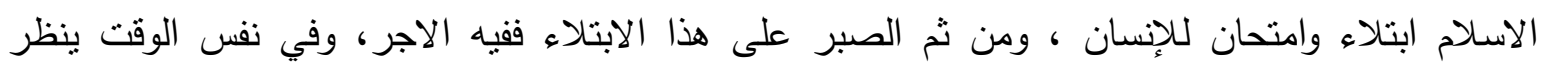

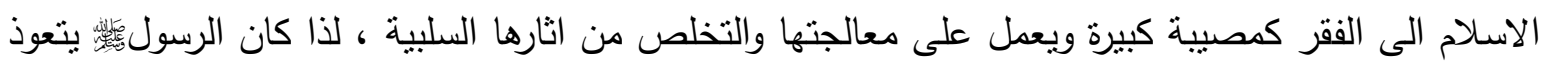
من الفقر فيقول : (( اللهم اني اعوذ بك من الفقر والقلة والذلة ، واعوذ بك من ان اظلم او أظلم)) (من) . اما العوامل الاجتماعية والتي تؤثر سلبا كثيرة ومنها : الصداقة السيئة والتي تؤدي بالفرد الى ارتكاب الفواحش والموبقات ، وقد حذرنا رسول اله صلى الله عليه وسلم من الخليل السوء فقال : (( الرجل على دين

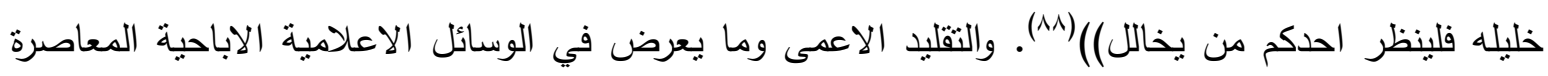

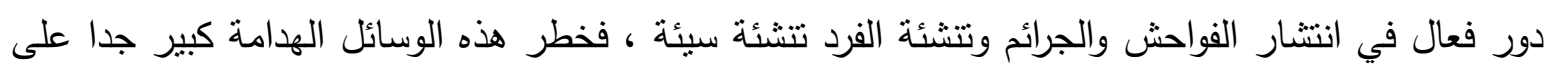
سلوك الفرد ، فكم من العوائل صارت ضحية مشاهد خليعة ومشاهد اجرامية ، وكم من فتاة انجرفت وراء ما هاه

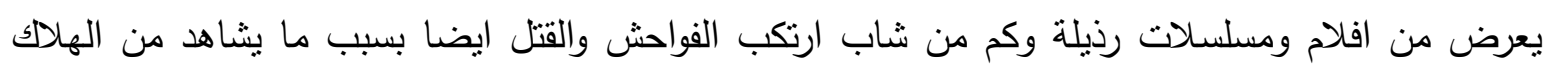
والاجرام • وللصراع الطائفي والتعصب للمذهب او القومية اثر كبير ايضا في ارتكاب الجرائم ، لذا ارشدنا الله

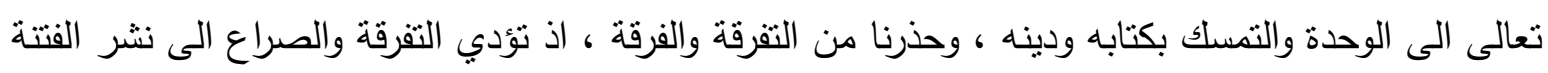

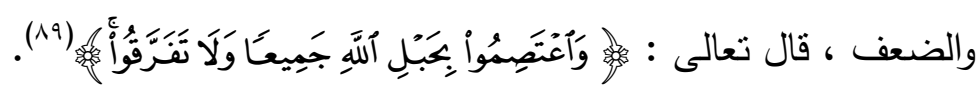

والاسلام ينكر وجود علاقة بين السلوك الاجرامي والسمات الخلقية من العيوب والنقائص ، لان الاسلام

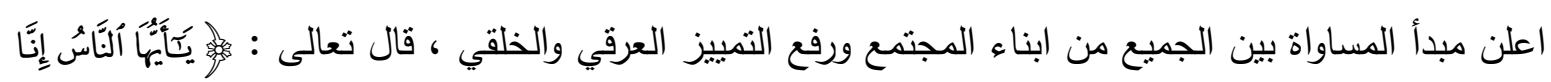

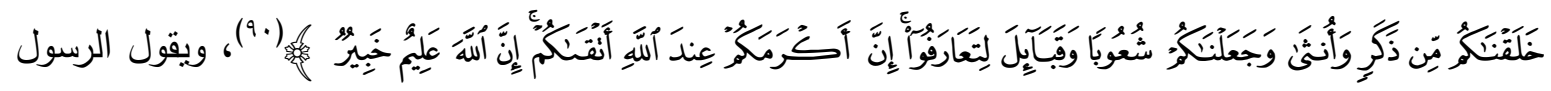

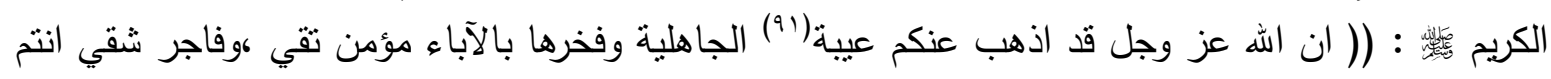

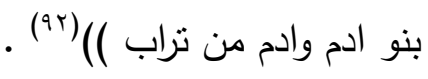

\section{المبيث الثالث : السياسة الشرعية لوقاية المتمع من الجريمة ومعالجتها.}

الهطلب الاول : الوسائل الوقائية التي تقيى الفرد من ارتكاب اي عمل اجرامي .

ان الاسلام اهنم اهتماما كبيرا بالوسائل الوقائية وهذه الوسائل منقسمة تبعا للدوافع المؤدية الى ارتكاب

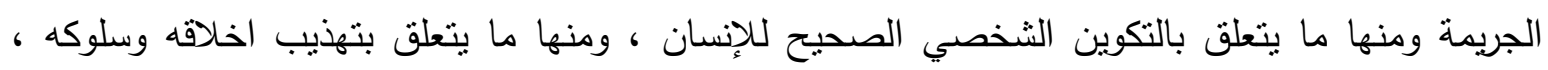


ومنها ما يتعلق بسلوك الانسان بالبيئة والمجتمع الذي يعيش فيه ـ نلاحظ ان في الاسلام عوامل كثيرة تساعد

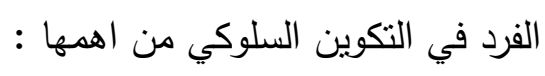

اولا : حسن اختيار الزوجة الصالحة : اكثر العوامل والاخلاق التي يكسبها الطفل من ابويه وخصوصا الام اذ اذذا هي المربية الاولى له ، لها دور كبير في بناء شخصية الطفل منذ نعومة اظفاره وتربيته تربية اخلاقية دينية

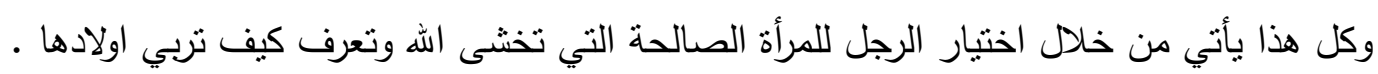
ثانيا : التربية البيتية الصحيحة ـ يستحب لوالدي الطفل مراعاة الهدي النبوي في احكام المولود ، وذللك كالآذان

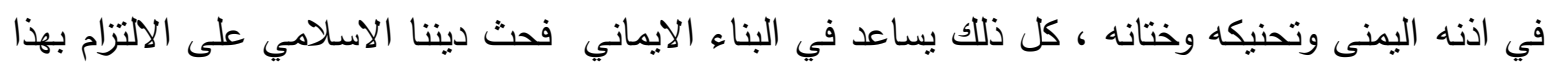
الجانب ورباهم على الخير ومكارم الاخلاق والابتعاد عن الثر والفساد ، والاسلام قد اهتم بحماية الاسرة من

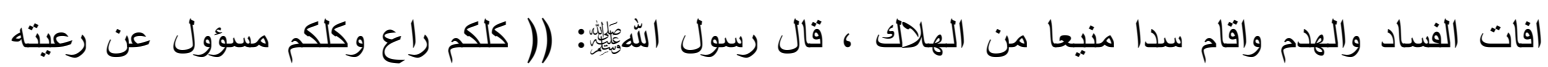

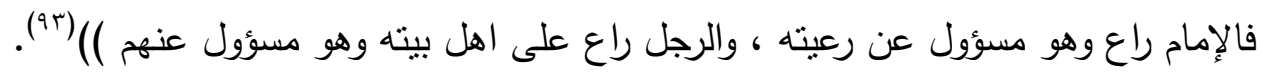

\section{الهطلب الثاني : وسائل تتعلوق بـتهذيب النفسر للوقاية من الجربيمة .}

العامل النفسي من اكبر العوامل الدافعة بالمرء الى ارتكاب الجريمة فمن اجل ازالة هذا الدافع لابد من

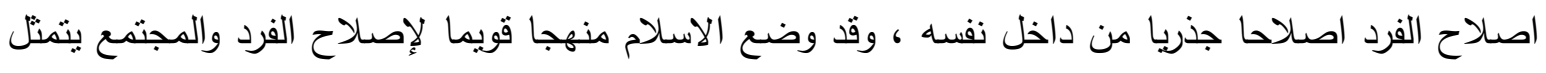

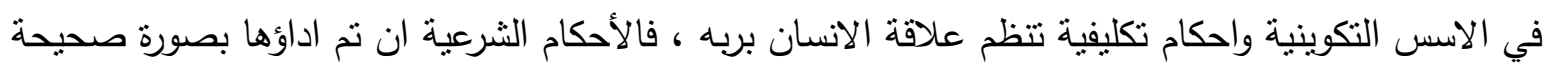

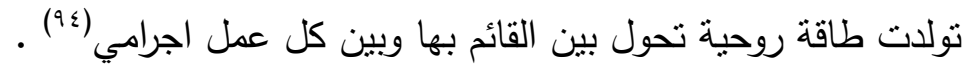

ان الرقابة التي تكون في داخل الانسان وهي الخوف من الله تعالى تجعله يتخذ السلوك السليم ويبتعد

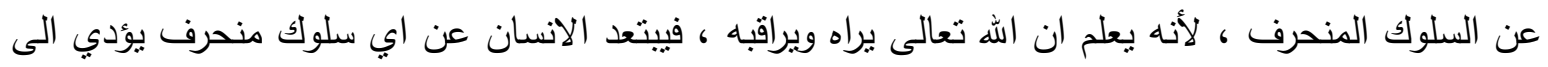
العقاب(90). وان النفس البشرية وعن طريق شهوتي البطن والفرج قد تدفع بالإنسان الى اتباع سبل الثبطان والابتعاد عن اوامر الرحمن ، فان الطريقة العلمية لضبط النفس عن هاتين الثهوتين هو الصوم فانه احفظ

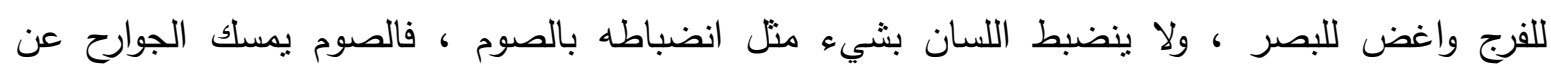
استخدامها في اي سلوك اجرامي(19) .

\section{المطلب الثالث : وسائل مكافهة الدوافم البيئية والاجتما عية لارتكاب الجربيمة .}

اذا كانت هنالك عوامل بيئية واجتماعية تسبب ارتكاب الجريمة ، فالإسلام قد عالج هذه العوامل بما

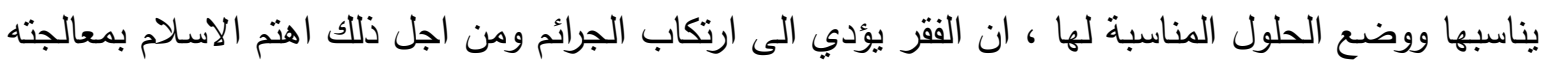
اهنماما كبيرا ووضع العلاج لهذه المشكلة وهو تشريع فرض الزكاة ، تحديد نسبة مئوية تؤخذ من الاغنياء

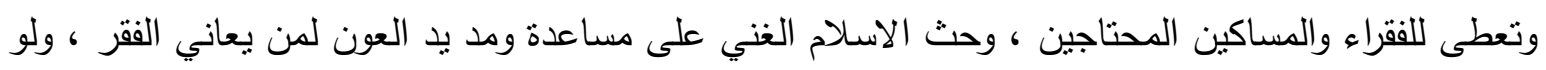

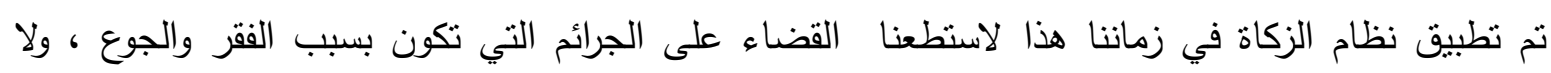

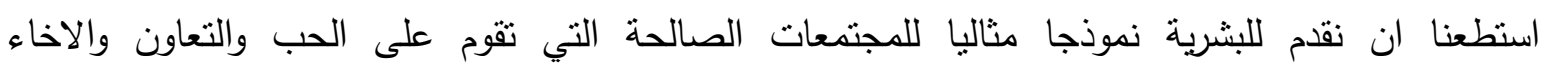

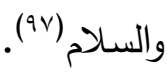

اذا كانت هناك عوامل اجتماعية وسياسية واقتصادية واعلامية لارتكاب الجريمة ، فالإسلام يحرص كل الحرص على تربية المجتمع المسلم تربية امتثال بأوامر الاسلام ونواهيه ، ارشادا للخير والسعادة ، ومنهج لأنيه 
الاسلام اذ يمر بمراحل لتربية الابناء والجيل تبدأ بتكوين الثخصية المسلمة من تربية الوالدين لولدهما وطاعة

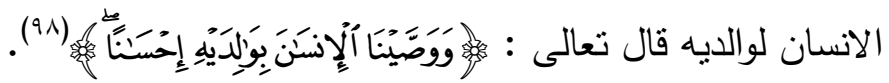

ومع اهتمام الاسلام بصلاح الفرد والمجتمع تبقى هناك نفوس شريرة ضعيفة لا تتعظ بأوامر ولا نواهي

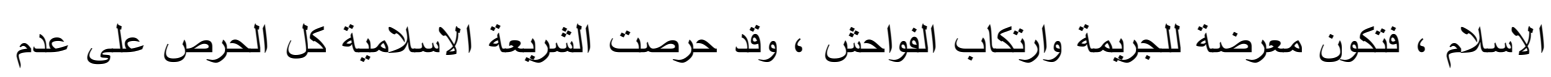
تطبيق العقوبة ان امكن قبل الاصلاح ، قال تعالى : مممج(99) ، ففي هذه الآية تبيان معالم الانبياء والرسل جعل العقوبة اخر ما يلجا اليه في نظام الحكم في الاسلام .

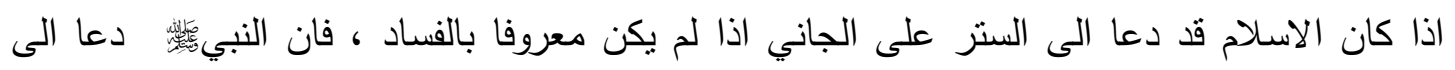

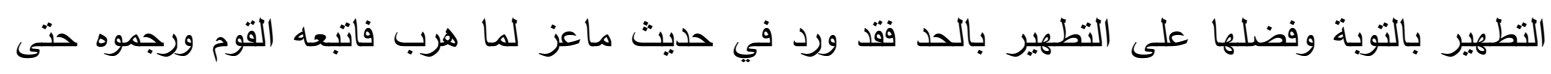

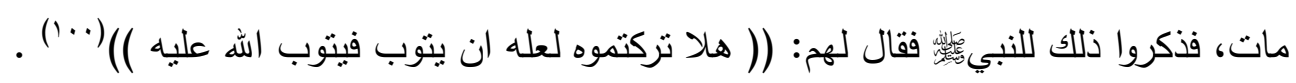
اذا كانت التوبة لا نسقط بها حقوق العباد فقد حث الاسلام اولياء المقتول على العفو والصلح قال تعالى

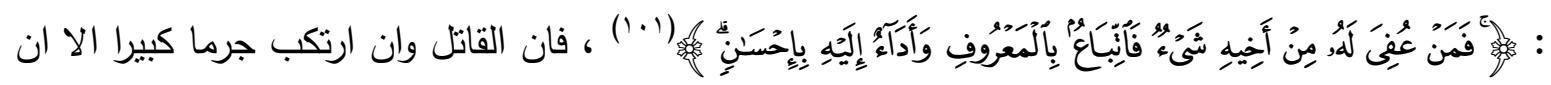

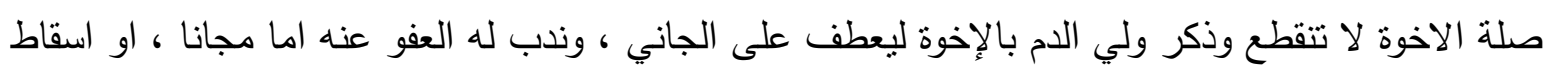

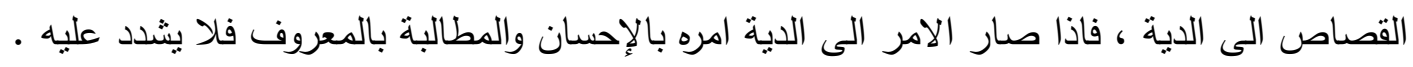
وقد حث النبي

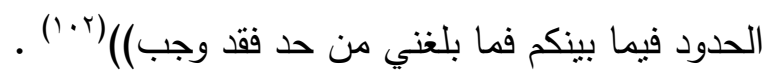

\section{الخاتمة}

بعد هذه الرؤية الفاحصة لموضوع (الوقاية من الجريمة في الثريعة الإسلامية ) فقد خرجت بالنتائج الآتية:ا . بين البحثإن نظام العقوبات من الأنظمة المهمة في بناء ركيزة كل دين إذ لايمكن لأي دين إن بيتمر

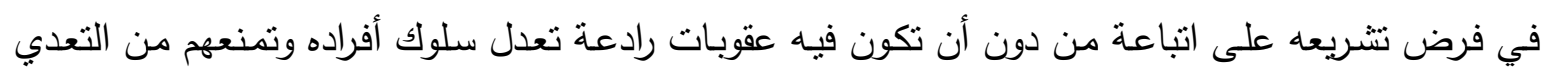

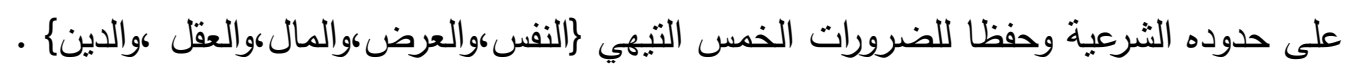

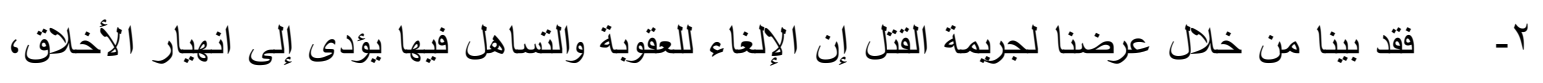

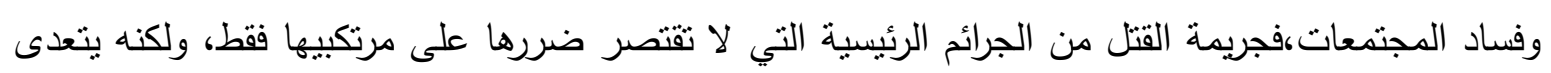

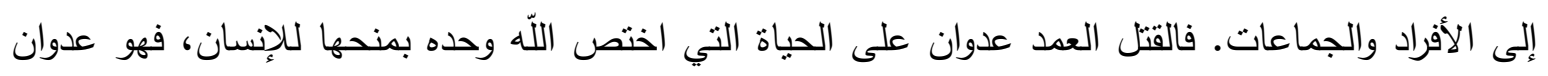
على حق اللّه، زِد على ذلك ما يترتب على هذه الجريمة من الاستهانة بحرمة الدماء، وثورت الأحقاد والعداوات، وإثاعة الفتن والذعر بين الناس؛ ولذلك كان قتل نفس واحدة بمثابة عدوان على البشرية . r- ـ وقد تبين من خلال البحث أن الإسلام قد توسط الحكم في مسألة القتل العمد فقد فرض فيه ثلاثة أحكام وصاحبه مخير فيها بين القود والعفو والدية. 


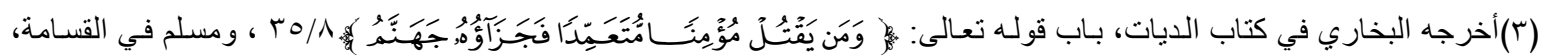

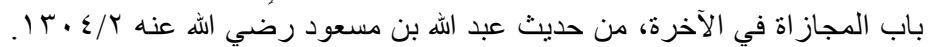

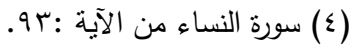

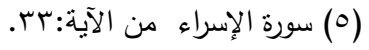

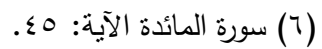

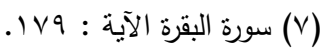

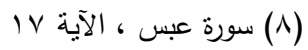

(9) تاج العروس من جوهرة القاموس لمحمد بن محمد بن عبد الرزاق الحسيني ، تحقيق: مجموعة من المحققين، دار الهاية.

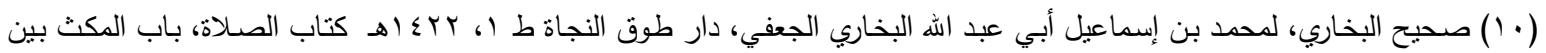

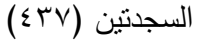

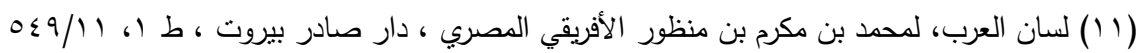

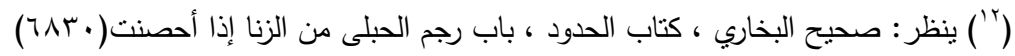

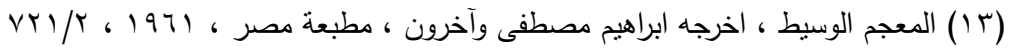

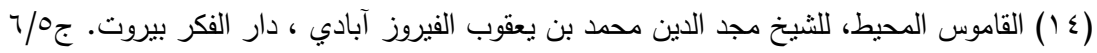

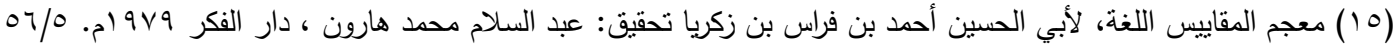

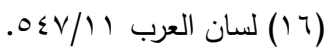

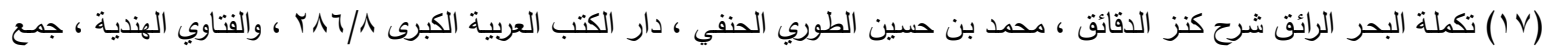

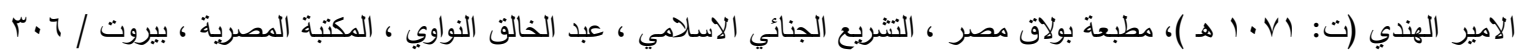

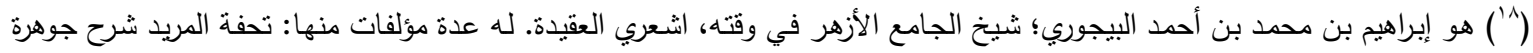

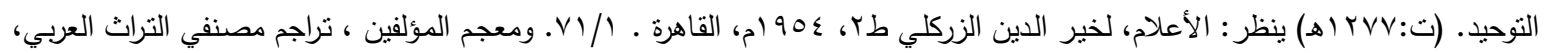

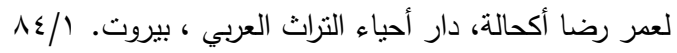

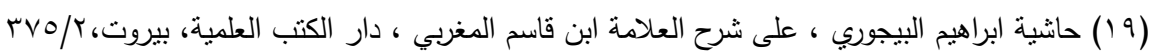

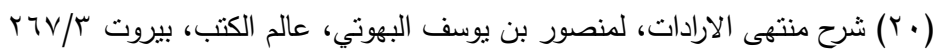

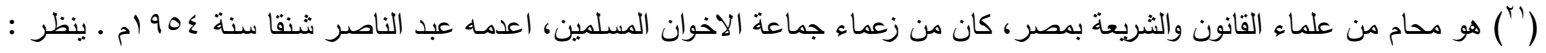

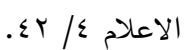

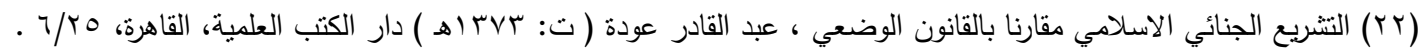

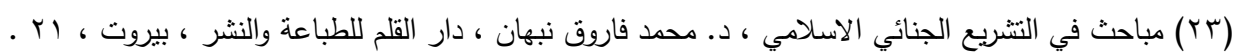
ris)

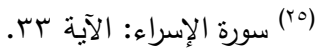

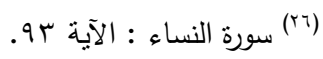

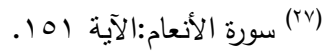

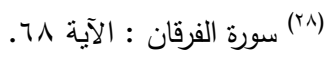

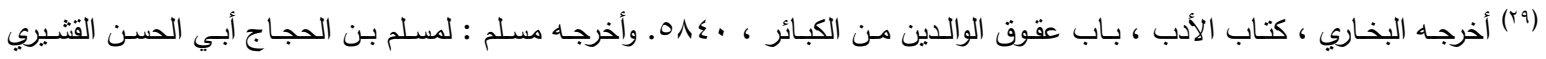

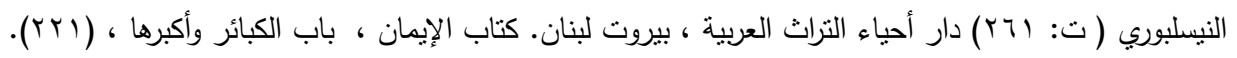

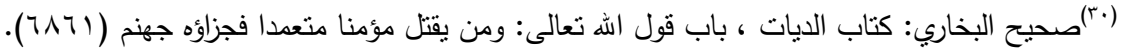

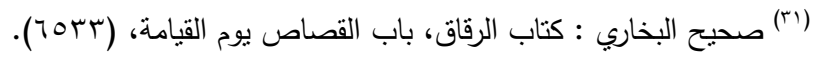

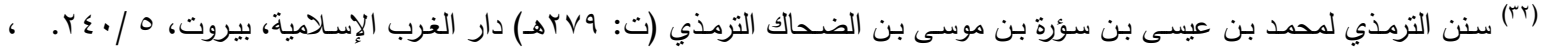

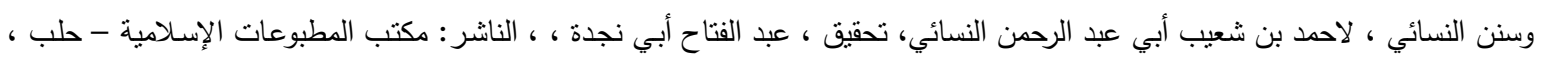

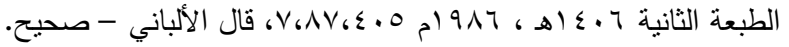

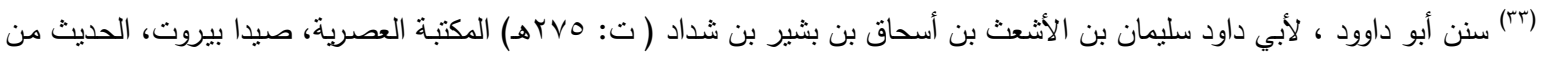

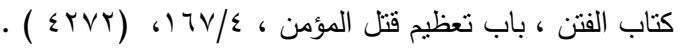

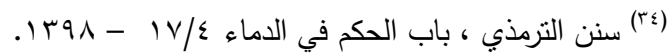




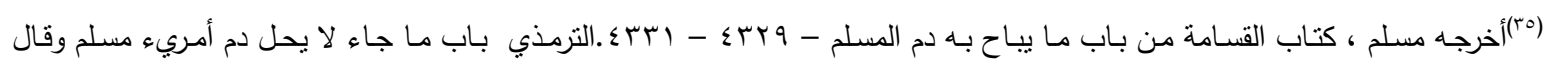

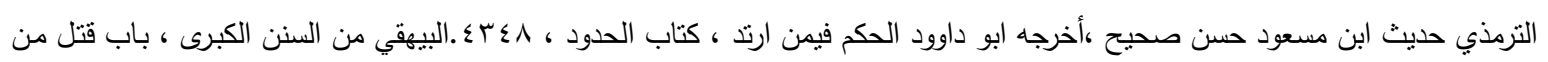

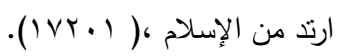

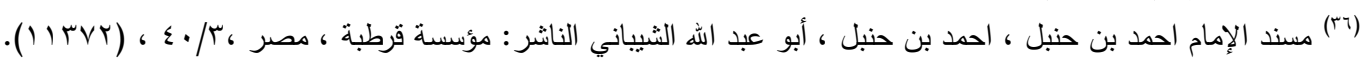

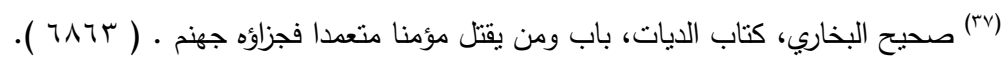

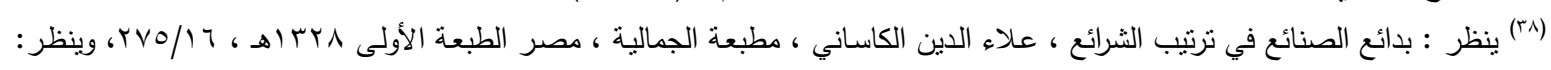

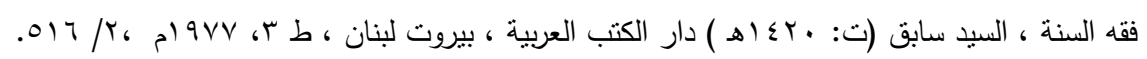

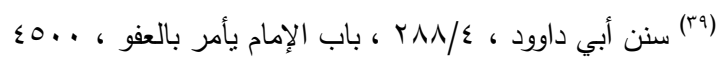

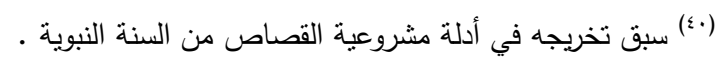

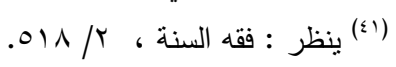
(r)

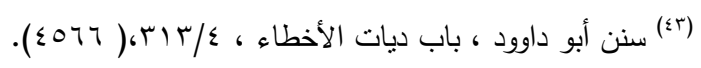

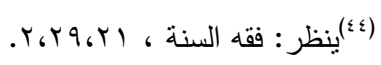

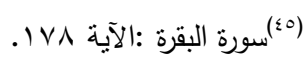

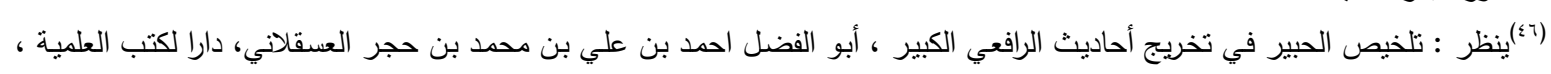

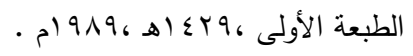

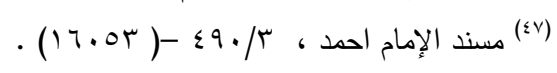

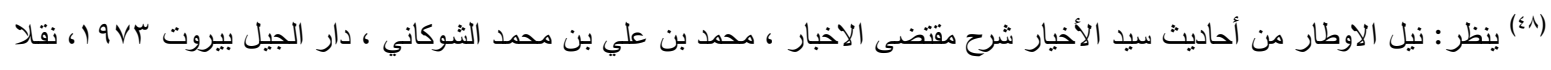

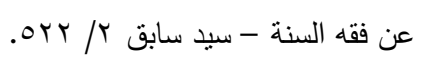

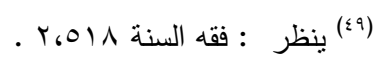

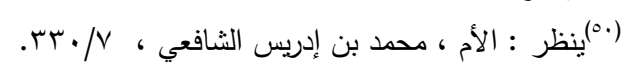

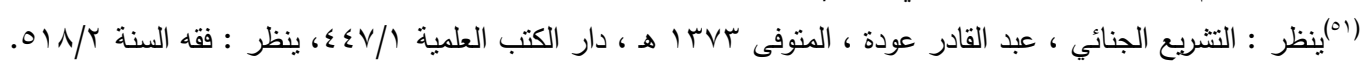

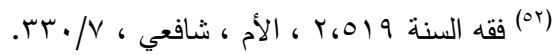
(Or)

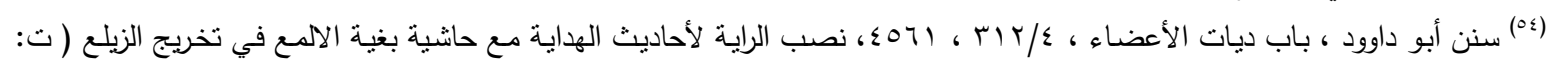

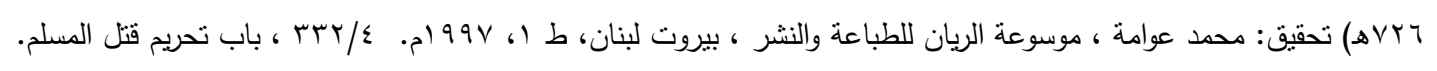

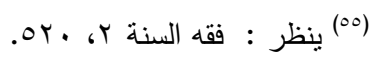

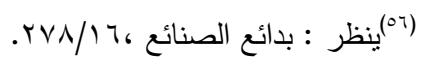

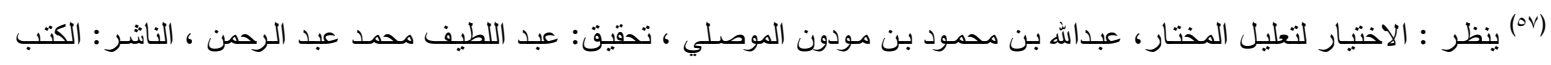

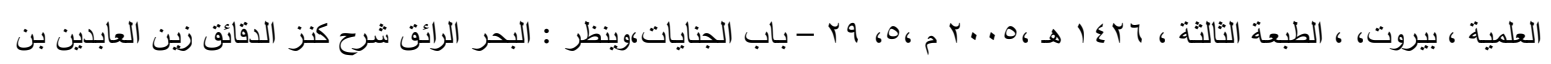

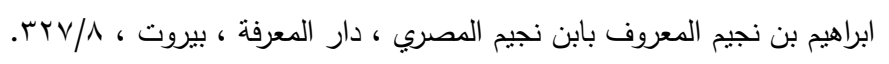

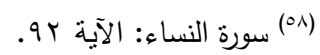

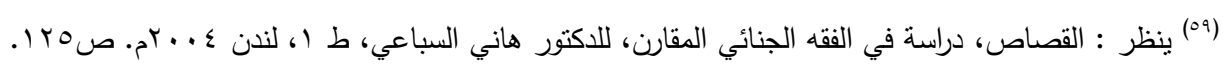

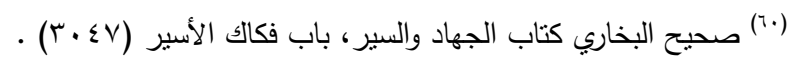

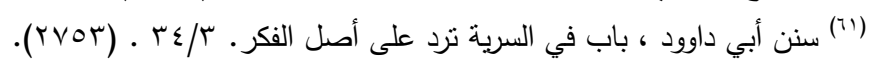

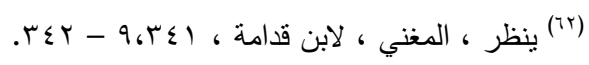

(r)

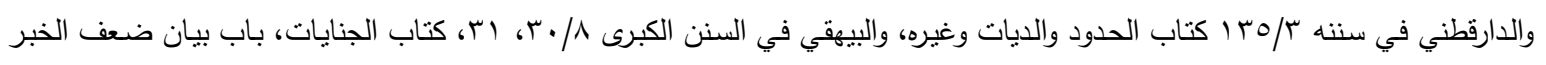

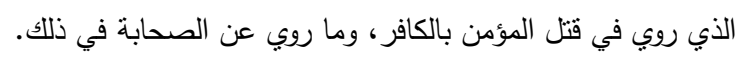

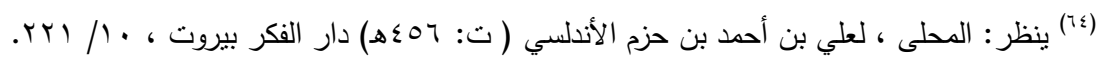

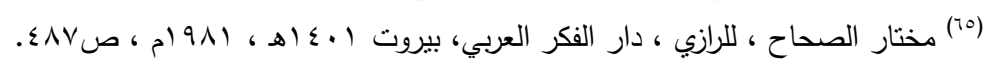

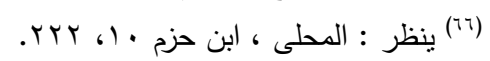




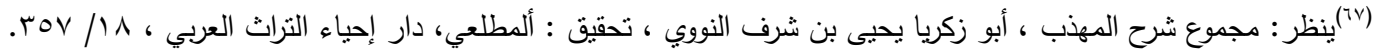

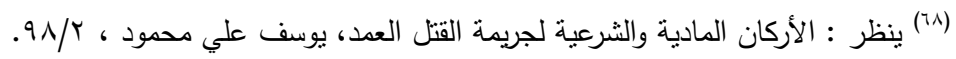
(79)

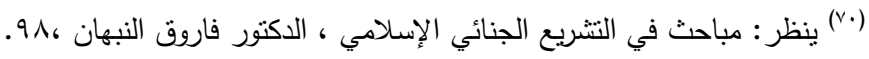

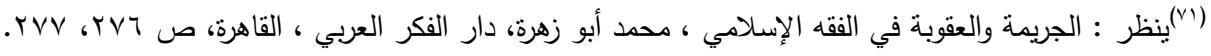

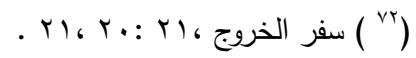
(VT)

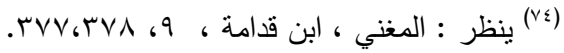

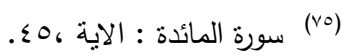

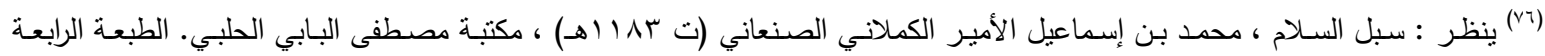

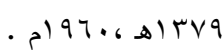

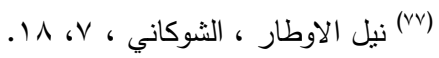

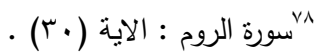

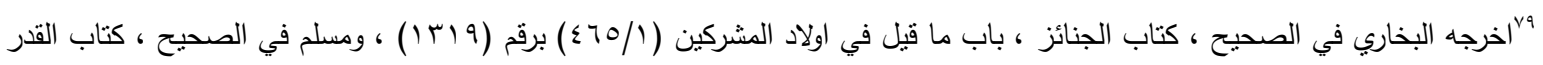

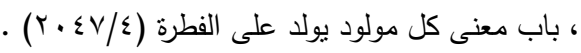

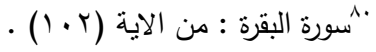

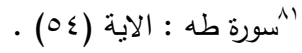

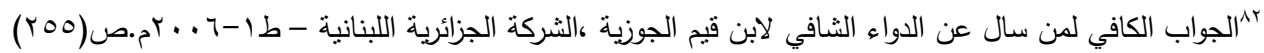
كَ

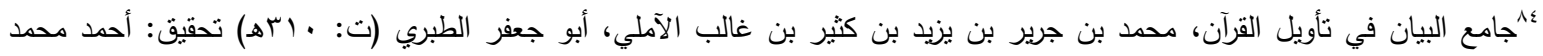

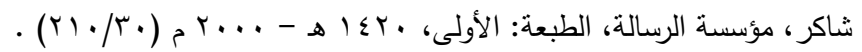

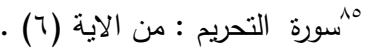

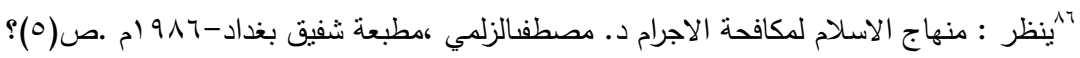

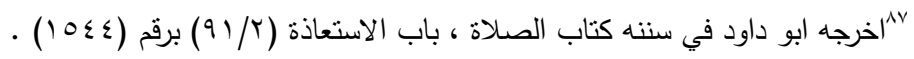

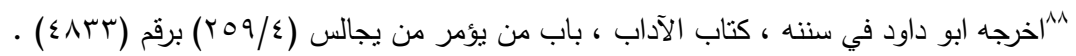

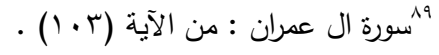

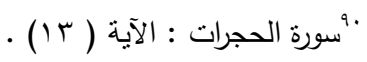
'العيبة : يعني الكبر ، ينظر : النهاية في غريب الحديث والاثرمجد الدين أبو السعادات المبارك بن محمد بن محمد بن محمد بن عبد الكريم،

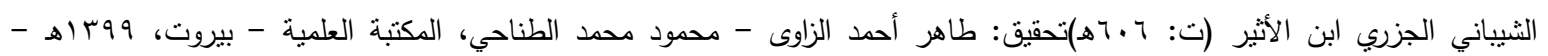
. (9V9

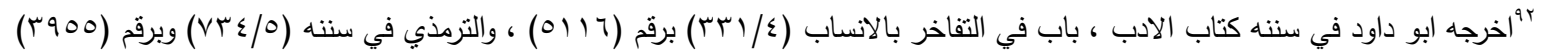

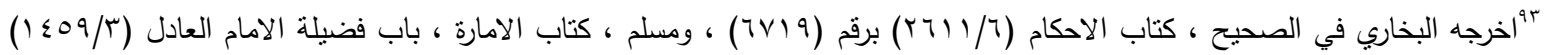
برقم (1) ( 1 ( )

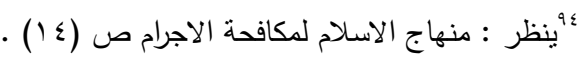

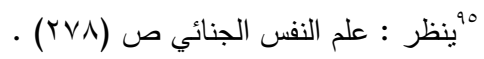

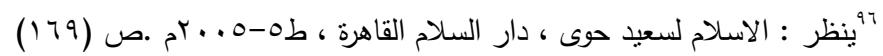

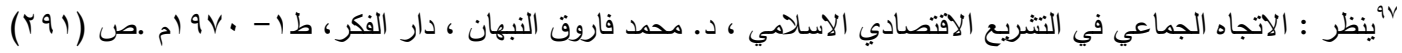
19 سورة الاحقاف : من الاية (10) .

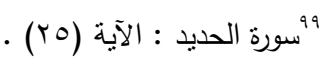




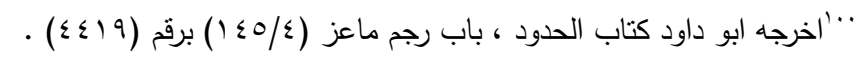

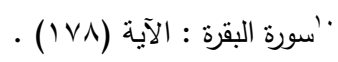

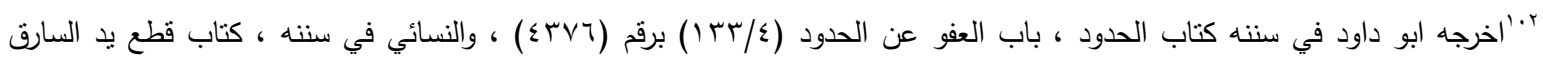
• برقم ( ( $(\Sigma \cdot / \wedge)$

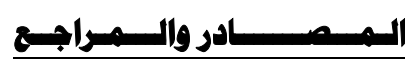

القرآن الكريم.

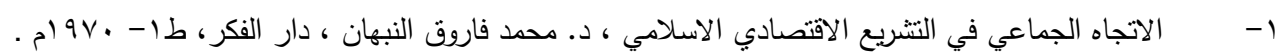

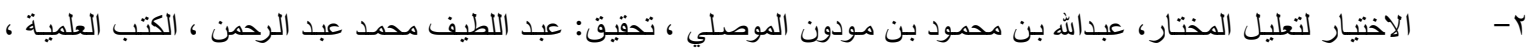

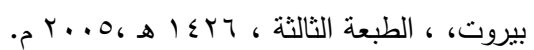

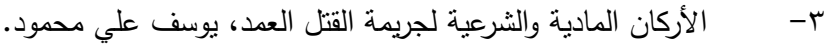

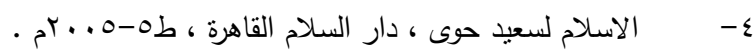

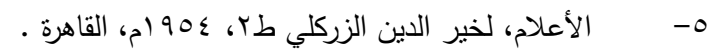

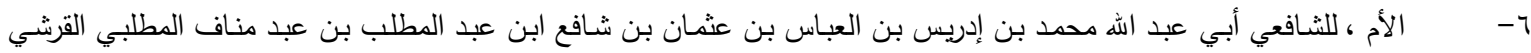

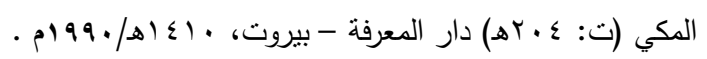

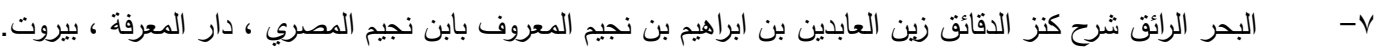

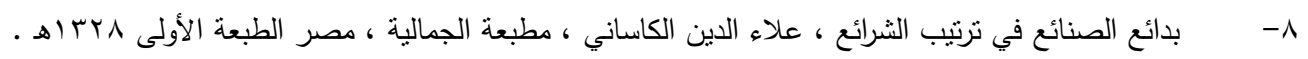

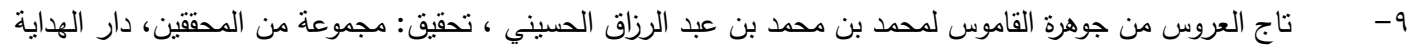

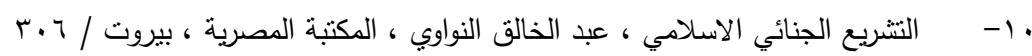

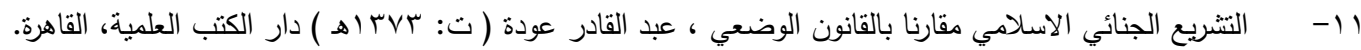

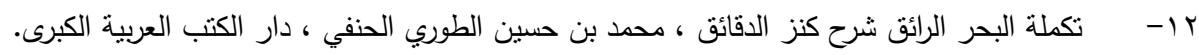

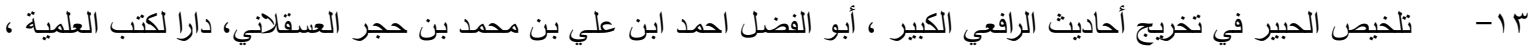

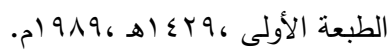

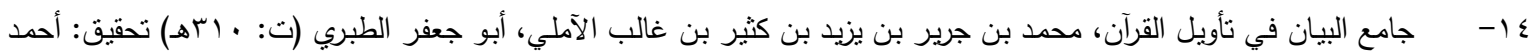

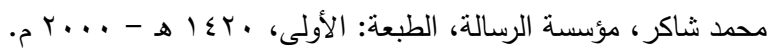

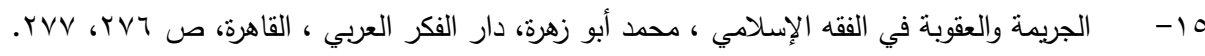

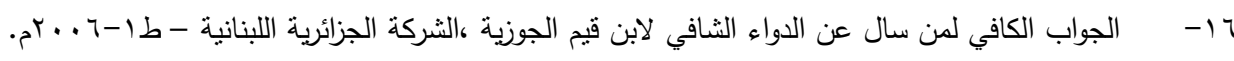

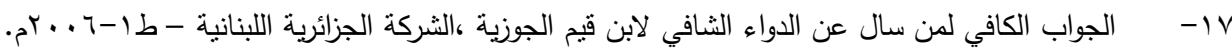
11 11- حاثية ابراهيم البيجوري ، على شرح العلامة ابن قاسم المغربي ، دار الكتب العلمية، بيروت.

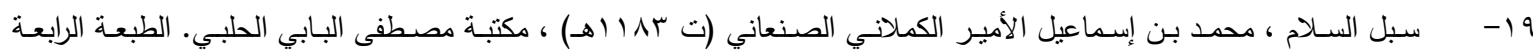

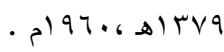

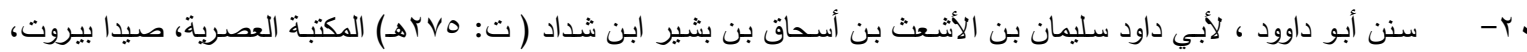
الحديث من كتاب الفتن ، باب تعظيم قتل المؤمن.

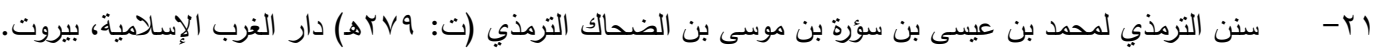

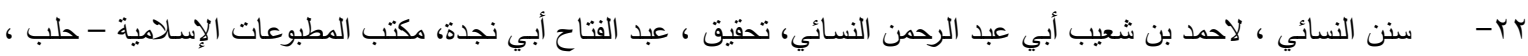

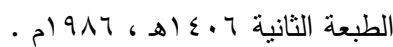
بr- شرائع الإسلام في الفقه الجعفري - منشورات دار مكتبة الحياة ، بيروت. ع

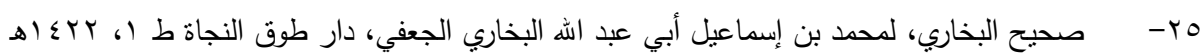

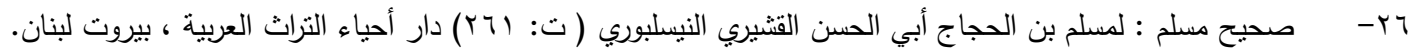

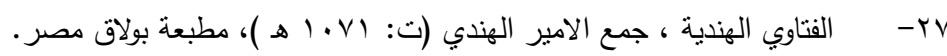

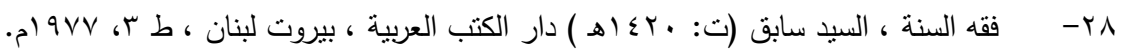


qج- القاموس المحيط، للثيخ مجد الدين محمد بن يعقوب الفيروز آبادي ، دار الفكر بيروت.

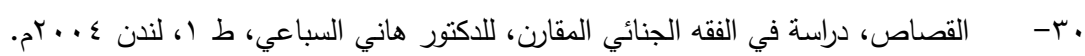

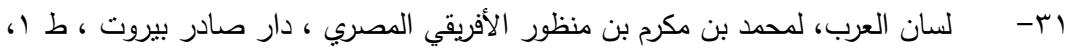

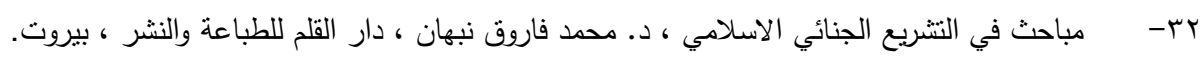

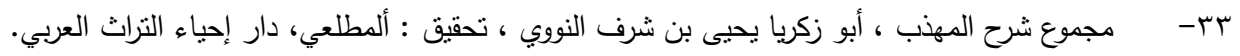

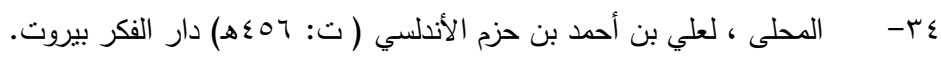

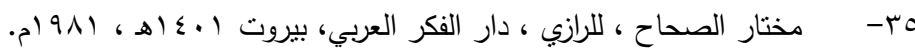

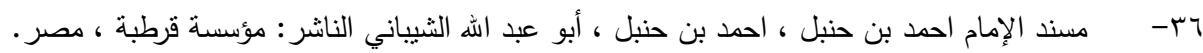

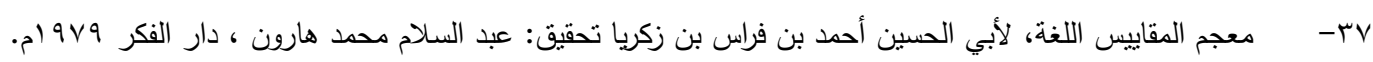

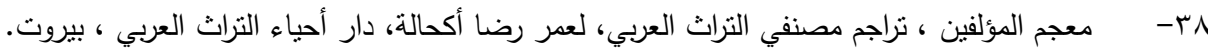

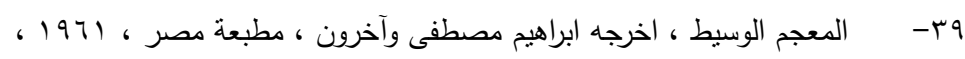

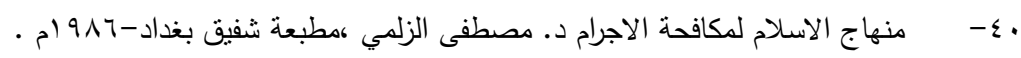

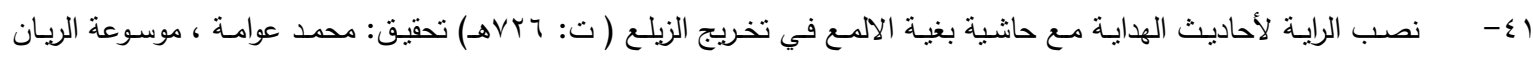

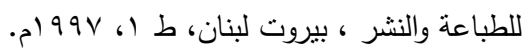
بـ - النهاية في غريب الحديث والاثر مجد الدين أبو السعادات المبارك بن محمد بن محمد بن بن محمد بن عبد الكريم، الثيباني الجزري

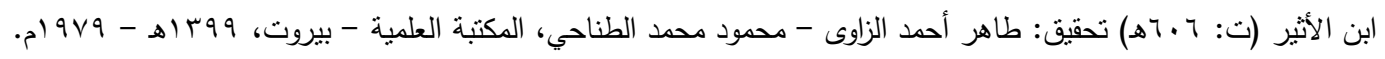

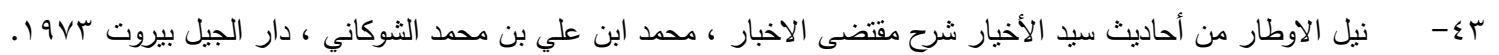

